\title{
Cyclization Reaction of Peptide Fragment Ions during Multistage Collisionally Activated Decomposition: An Inducement to Lose Internal Amino-Acid Residues
}

\author{
Chenxi Jia, Wei Qi, and Zhimin He \\ Chemical Engineering Research Center, School of Chemical Engineering and Technology, Tianjin University, \\ Tianjin, People's Republic of China
}

\begin{abstract}
During characterization of some peptides (linear precursors of the cyclic peptides showing potential to be anticancer drugs) in an ion trap, it was noted that many internal amino acid residues could be lost from singly charged $b$ ions. The phenomenon was not obvious at the first stage of collisionally activated decomposition (CAD), but was apparent at multiple stages of CAD. The unique fragmentation consisting of multiple steps is induced by a cyclization reaction of $b$ ions, the mechanism of which has been probed by experiments of $\mathrm{N}$-acetylation, $\mathrm{MS}^{\mathrm{n}}$, rearranged-ion design, and activation-time adjustment. The fragmentation of synthetic cyclic peptides demonstrates that a cyclic peptide intermediate (CPI) formed by $b$ ion cyclization exhibits the same fragmentation pattern as a protonated cyclic peptide. Although no rules for the cyclization reaction were discerned in the experiments of peptide modification, the fragmentations of a number of b ions indicate that the "Pro and Asn/Gln effects" can influence ring openings of CPIs. In addition, large-scale losses of internal residues from different positions of a-type ions have been observed when pure helium was used as collision gas. The fragmentation is initiated by a cyclization reaction forming an a-type ion CPI. This CPI with a fixed-charge structure cannot be influenced by the "Pro effect", causing a selective ring opening at the amide bond Pro-Xxx rather than Xxx-Pro. With the knowledge of the unique fragmentations leading to internal residue losses, the misidentification of fragments and sequences of peptides may be avoided. (J Am Soc Mass Spectrom 2007, 18, 663-678) (c) 2007 American Society for Mass Spectrometry
\end{abstract}

$\mathrm{T}$ Tandem mass spectrometry (MS/MS) plays a key role in the characterization of the primary structures of proteins and peptides. In the last two decades, innovations in MS instrumentation and techniques fundamentally drove the development of proteomics $[1,2]$. So far, two approaches have been developed for protein identification [3]: top-down [4] and bottom-up $[5,6]$ sequencings. For the top-down sequencing, the protein sample without enzymatic digestion is transferred into the gas phase intact, which has the potential for $100 \%$ sequence coverage of the protein and improved detection of post-translational modifications [4]. The bottom-up sequencing requires MS/MS analysis of the proteolytic fragments and database searching using algorithms such as Mascot and Sequest $[5,6]$. In addition, structural elucidations of natural or synthetic peptides, including linear peptides [7, 8], cyclic peptides [9, 10], and peptide analogues [11] also rely on MS/MS analysis. Undoubtedly, all of the appli-

Published online January 17, 2007

Address reprint requests to Dr. W. Qi, Chemical Engineering Research Center, School of Chemical Engineering and Technology, Tianjin University, Tianjin 300072, People's Republic of China. E-mail: qiwei@tju.edu.cn cations described above are based on understanding the dissociation mechanisms of peptides, which have been well summarized in recent reviews [12-16]. However, conventional knowledge of fragmentation pathways and rules cannot reasonably explain many anomalous fragmentations. For example, some groups have reported that certain peptides show enhanced cleavage at special amino acid residues to produce incomplete sequence information [15]. Hence, the study on fragmention intensity relationship was of further concern and specially reviewed by Paizs and Suhai [16]. Also, another class of anomalous fragmentations introduced in this paper should receive attention.

For peptide sequencing, the ideal fragmentation pattern of peptides is that the amino acid residues are sequentially lost from the $\mathrm{C} / \mathrm{N}$-terminus. However, if the residues are lost from the interior of the peptide chain, the peptide sequence will be easily misidentified. Referring to related literatures [17-23], we summarize this class of anomalous fragmentations accompanied by losses of internal amino acid residues into three steps (Scheme 1). (1) A cyclic peptide intermediate (CPI) is formed through a nucleophilic attack by the electronrich group on the electron-poor group of the peptide 


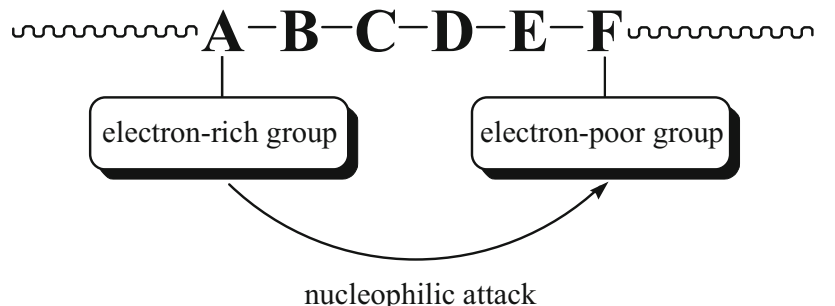

(i) cyclization
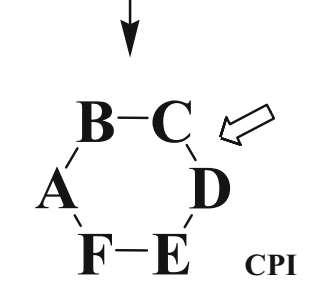

(ii) ring reopening

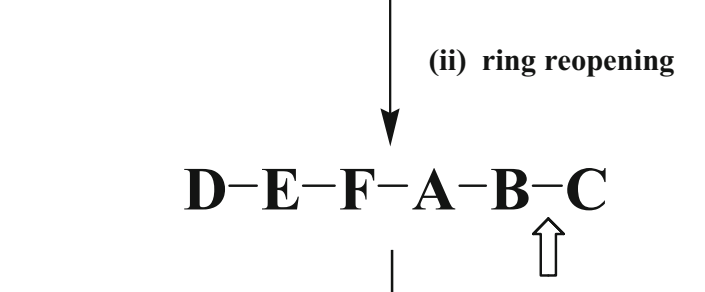

(iii) amide bond cleavage

\section{$\mathbf{D}-\mathbf{E}-\mathbf{F}-\mathbf{A}-\mathbf{B}$}

anomalous ion with internal residue loss

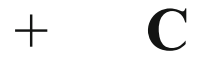

neutral loss of internal residue
Scheme 1

chain. (2) The CPI ring reopens at other sites, producing linear fragment ions where internal residues are relocated at the $\mathrm{C} / \mathrm{N}$-termini. (3) The linear fragment ions further dissociate via conventional fragmentation pathways, forming daughter ions with neutral losses of internal residues from the parent ion. Obviously, the cyclization reaction is critical for inducing this class of fragmentations. The related literature is briefly described as follows.

Tang et al. $[17,18]$ have reported a head to side-chain cyclization of $b^{2+}$ ions leading to internal residue losses, which proceeds via electrophilic attack by the protonated $\omega$-amino group of Lys (or Orn) in $[\mathrm{M}+\mathrm{H}]^{2+}$ on the backbone amide carbonyl groups at/near the C-terminus. The analogous behavior of Lys was also observed by Fuchs and Budzikiewicz [21]üinüMS/MSüanalysisü of pyoverdins.üSubsequently, üYagüeüetüal.ü[22]üdescribedüa head-to-tail cyclization of $\mathrm{b}^{2+}$ ions, arising from a nucleophilic attack by the $\mathrm{N}$-terminal nitrogen over the carbonyl carbon of one peptide bond. The investigations described above focused on doubly charged ions. For singly charged ions, ưVachetïetüal.ư[19] üsuggestedüthatütheü̈-typeüonïcan undergo a head-to-tail cyclization reaction accompanied by an $\mathrm{NH}_{3}$ loss from N-terminus, which was also proposedibyiHarrisonäandi̛̊ oungư[24].üÄ̈similarüdissociation patternüwasüobservedübyüCraigüandüTaylorü[20]üduring characterization of plicatamide 1 . Recently, in the negative ion spectra of citropin 1.1 and analogues, Brinkworth et al. [23] üfoundüthatütheülossüofüanüinternalüValüresidueüwas induced by a head-to-tail cyclization between the $\mathrm{CONH}^{-}$ group of the C-terminus and the carbonyl group of the Ser-Val amide bond. Coincidentally, when our manu-

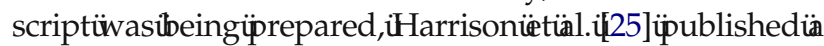
communication, which showed that $\mathrm{b}$ ions could be cyclized by attack of the N-terminal amino group on the carbonyl carbon of C-terminal oxazolone ring. These findings described above suggest that the cyclization reactions leading to internal residue losses frequently occur during peptide fragmentations and need to be further studied.

Inüourüpreviousüworkư[26],ünsingümultistepüMS/MSün an ion trap we sequenced some cyclic peptides and observed some anomalous ions with internal residue lossesüasüreportedübyüNNgokaüandüGrossü[10]üasüwellüas Stefanowiczü[27].üInütheüpresentüwork,üweüdivertüour attention to investigating the unique fragmentation of $b$ ions from linear peptides. At the first stage of CAD, this unique fragmentation of singly charged $\mathrm{b}$ ions is difficult

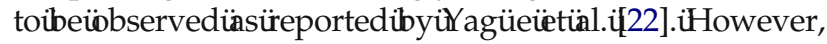
under multistage CAD almost all of the investigated $b$ ions (containing three to seven residues) notably display the unique fragmentation pattern, which is quite intensive. This paper focuses on studying the cyclization mechanisms of $\mathrm{b}$ ions, which are probed by the experiments including $\mathrm{N}$-acetylation, $\mathrm{MS}^{\mathrm{n}}$, rearranged-ion design, activation-time adjustment, synthetic cyclic peptide fragmentation and peptide modification. Particular attention is paid on discussing the relationship between the fragmentation patterns of the CPI produced by $b$ ion cyclization and the protonated cyclic peptide produced by electrospray ionization (ESI). We attempt to introduce the fragmentation mechanism of cyclic peptides into CPIs and to find some valuable predictive rules, e.g., the "Pro and

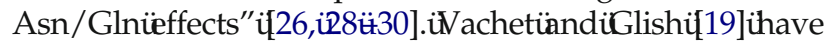
reported that residues can be lost from the second positions of C-termini of a-type ions when a mixture of helium and $5 \%$ xenon was used as collision gas in an ion trap. Following their research, we observed this phenomenon using $100 \%$ helium as collision gas. In addition, it was found that not only the internal residues at the second positionüofüC-terminusü[19] ïbutüalsoüthoseüatüotherüpositions could be eliminated. Moreover, another interesting phenomenon is that the amide bond Pro-Xxx rather than Xxx-Pro in CPIs formed by a-type ion cyclization exhibits enhanced cleavage, and a tentative explanation has been proposed in this research.

\section{Experimental}

\section{Materials and Reagents}

Wang-resin, Fmoc-amino acids, and coupling reagents for peptide synthesis were purchased from GL Biochem 
(Shanghai, China). All solvents for peptide synthesis were commercial analytical grade and were redistilled before use. HPLC-grade formic acid and acetonitrile were supplied by Merck (Darmstadt, Germany).

\section{Peptide Synthesis and Chemical Modifications}

The linear peptides were prepared manually using Wang-resin as solid support following the Fmoc methodology. The obtained linear peptides were cyclized in solution to yield the cyclic peptides. The details were describedünüourüpreviousüreportsü[26,ỉ31].üAcetylation of the free amine moiety at the N-terminus of peptide was achieved by adding $50 \%$ (vol/vol) acetic anhydride in pyridine to the peptide-resin following a final deprotection step (before the final cleavage from resin).

\section{Mass Spectrometry Conditions}

Experiments were performed with a Finnigan LCQ ion-trap mass spectrometer (San Jose, CA) equipped with an ESI source. The spray needle was set at a potential of $5.0 \mathrm{kV}$ and a nitrogen sheath gas flow of 20 (arbitrary units) was used to stabilize the spray. The capillary temperature was maintained at $200^{\circ} \mathrm{C}$. The tube-lens offset was $20 \mathrm{~V}$ and the electron multiplier voltage was $-800 \mathrm{~V}$. Helium gas was introduced into the ion trap to improve the trapping efficiency of the analyte ions introduced into the ion trap. The background helium gas also served as the collision gas during the CAD event. A $50 \mathrm{pmol} / \mu \mathrm{l}$ solution of peptide in 50:50 ( $\mathrm{vol} / \mathrm{vol}$ ) acetonitrile/ $\mathrm{H}_{2} \mathrm{O}$ containing $1 \%$ formic acid was infused into the mass spectrometer at a flow-rate of $2 \mu \mathrm{l} / \mathrm{min}$ by syringe pump. Isolation widths of $1.0 \mathrm{~m} / \mathrm{z}$ and activation times of $30 \mathrm{~ms}$ were used at each stage of CAD; 400 scans were averaged. Spectra were acquired in the centroid mode.

\section{Nomenclature for Labeling the Fragment Ions}

The nomenclature for labeling the conventional fragment ions of peptides was developed by Roepstorff andüFohlmannü[32]üandüBiemannü[33].üAnüextension [18,ü22]üofüthisünomenclatureüisüusedütoülabelüthe anomalous ions with internal residue losses. The general formula is " $x_{n}-A A . .$. " where " $x_{n}$ " is the designation for the ion such as " $a_{n}$ " and " $b_{n}$ " and "AA...", are the one letter codes of lost amino acid sequence. In addition, "**" and " 0 " superscripts, respectively, denote neutral loss of one ammonia molecular and one water molecule; "E" superscript denotes N-acetylation fragment ion. Because all ions in this study are singly charged, for simplicity no special symbol is used to label charges.

\section{Results and Discussion}

\section{Deduction for Cyclization Reaction of Singly Charged b-Type Ions}

Finding of the unique fragmentation. Initially, we were interested in sequencing cyclic peptides with antitumor activities and in studying the fragmentation mechanismsüusingümultistepiCADününüonitrapi[26]. Sequencing cyclic peptides usually depends on detectionüofubüionsü10].üHowever, üsomeiCADüspecträ̈ofib ions present the rearranged fragment ions with losses ofüinternalüaminoüacidüresiduesü[10,ü26,ü27].üInüthis work, we further study the $b$ ions arising from the linear precursors of these cyclic peptides to verify whether it is a common phenomenon. In the first step, the ESI-produced $[\mathrm{M}+\mathrm{H}]^{+}$of the linear peptides were subjected to the first stage of CAD to produce $\mathrm{MS}^{2}$ spectra. No anomalous ions were observed obviously (Figure S1 in Supplementary Material which can be found in the electronic version of this article). In the second step, the $b$ ions were selected from the obtained $\mathrm{MS}^{2}$ spectra and subjected to the second stage of CAD to produce $\mathrm{MS}^{3}$ spectra. The obtained data indicate that almost all of the investigated $b$ ions exhibit the unique fragmentation pattern with internalüresidueüossesǘseeitheïsecondïcolumnünüTableüi) .

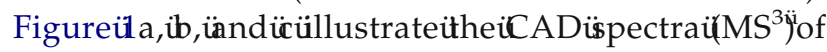
the $b_{6}, b_{5}$, and $b_{4}$ ions from peptide PLIFSPI (a precursorïofiStylopeptideül i[34], ̈̈respectively.ïFigure $2 a$, ib, ünndücügiveitheiCADïspectraï(MS $S^{3 \ddot{j})}$ of the $b_{6}, b_{5}$ and $b_{4}$ ions from peptide PFNSLAI (a precursor of Stylostatinüi u[35], ürespectively.

Deduction for cyclization. The $\mathrm{MS}^{3}$ spectrum of $\mathrm{b}_{6}$

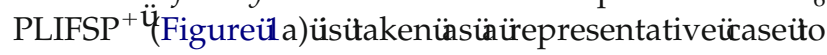
introduce the deduction process. According to conventional fragmentation rules, the $b_{6}$ ion dissociates mainly via $b_{n} \rightarrow b_{n-1}$ and $b_{n} \rightarrow a_{n}$ pathways to form lower $b$ - and

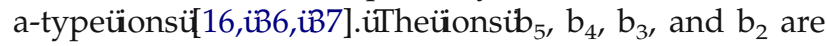
observedüclearlyüinütheüspectrum.üOnütheübasisüof

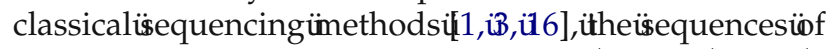
these $\mathrm{b}$ ions are determined as PLIFS ${ }^{+}, \mathrm{PLIF}^{+}, \mathrm{PLI}^{+}$, and $\mathrm{PL}^{+}$, respectively. Accordingly, the linear parent ion $b_{6}$ are identified as PLIFSP ${ }^{+}$. However, some anomalous ions formed via other fragmentation pathways reveal sequential elimination of residues from the interior of the parent ion $\mathbf{b}_{6}$. For example, $\boldsymbol{b}_{6}-\mathbf{S}$ at $m / z 568.7$ differs from $b_{6}$ at $m / z 655.8$ by $87.1 \mathrm{Da}$, the mass of a Ser residue. The mass differences among $b_{6}-S(m / z 568.7)$, $\mathbf{b}_{6}-\mathrm{FS}(\mathrm{m} / \mathrm{z} 421.7)$, and $\mathbf{b}_{6}-\mathrm{IFS}(\mathrm{m} / \mathrm{z} 308.6)$ are 147.0 and $113.1 \mathrm{Da}$, which respectively, correspond with the mass of Phe and Ile residues. Furthermore, the anomalous ions display the feature of b-type ions because sometimes there are a-type ions formed by a $\mathrm{CO}$ loss near them (the evidence shown at the end of the Exploring Predictive Rules section). Therefore, the sequences of $\mathrm{b}_{6}-\mathrm{S}, \mathrm{b}_{6}-\mathrm{FS}$, and $\mathrm{b}_{6}$-IFS are deduced as PPLIF $^{+}, \mathrm{PPLI}^{+}$, and $\mathrm{PPL}^{+}$, respectively. The sequence of their linear 
Table 1. b-Type ions undergoing cyclization reaction in this investigation

\begin{tabular}{|c|c|c|c|c|c|}
\hline \multirow{2}{*}{$\begin{array}{l}\text { Peptide } \\
\text { PLIFSPI }^{\mathrm{b}}\end{array}$} & \multicolumn{2}{|c|}{$\begin{array}{c}\text { Parent } b \text { ions } \\
\text { undergoing } \\
\text { cyclization reaction }\end{array}$} & \multirow{2}{*}{$\frac{\text { CPI formed by cyclization reaction }}{\text { cyclo(PLIFSP }+\mathrm{H})^{+}}$} & \multicolumn{2}{|c|}{$\begin{array}{l}\text { Preferential ring-opening } \\
\text { amide bond of } \mathrm{CPI}^{\mathrm{a}}\end{array}$} \\
\hline & $b_{6}$ & PLIFSP $^{+}$ & & Ser-Pro & Pro-Pro \\
\hline & $b_{5}$ & PLIFS $^{+}$ & cyclo $(\text {PLIFS }+\mathrm{H})^{+}$ & Ser-Pro & Leu-Ile \\
\hline & $b_{4}$ & PLIF $^{+}$ & cyclo $(\text {PLIF }+\mathrm{H})^{+}$ & Phe-Pro & Leu-Ile \\
\hline \multirow[t]{4}{*}{ PFNSLAI ${ }^{\mathrm{b}}$} & $b_{6}$ & PFNSLA $^{+}$ & cyclo $(\text {PFNSLA }+\mathrm{H})^{+}$ & Asn-Ser & Ala-Pro \\
\hline & $b_{5}$ & $\mathrm{PFNSL}^{+}$ & cyclo(PFNSL $+\mathrm{H})^{+}$ & Asn-Ser & Leu-Pro \\
\hline & $b_{4}$ & PFNS $^{+}$ & cyclo $(\text {PFNS }+\mathrm{H})^{+}$ & Asn-Ser & Ser-Pro \\
\hline & $b_{3}$ & $\mathrm{PFN}^{+}$ & cyclo $(\mathrm{PFN}+\mathrm{H})^{+}$ & $-{ }^{c}$ & $-{ }^{c}$ \\
\hline \multirow[t]{3}{*}{ IFSPIPb } & $b_{6}$ & IFSPIP $^{+}$ & cyclo $(\text {IFSPIP }+\mathrm{H})^{+}$ & Ser-Pro & Ile-Pro \\
\hline & $b_{5}$ & $\mathrm{IFSPI}^{+}$ & cyclo(IFSPI $+\mathrm{H})^{+}$ & Ser-Pro & Ile-Ile \\
\hline & $b_{4}$ & $\mathrm{IFSP}^{+}$ & cyclo(IFSP $+\mathrm{H})^{+}$ & Ser-Pro & Pro-lle \\
\hline \multirow[t]{3}{*}{ LPVNPFV $^{b}$} & $b_{6}$ & LPVNPF $^{+}$ & cyclo(LPVNPF $+\mathrm{H})^{+}$ & Asn-Pro & Leu-Pro \\
\hline & $b_{5}$ & LPVNP $^{+}$ & cyclo(LPVNP + H) ${ }^{+}$ & Asn-Pro & Leu-Pro \\
\hline & $b_{4}$ & $\mathrm{LPVN}^{+}$ & cyclo $(\text {LPVN }+\mathrm{H})^{+}$ & Asn-Leu & Val-Asn \\
\hline \multirow[t]{3}{*}{ VPVNPFV } & $b_{6}$ & VPVNPF $^{+}$ & cyclo(VPVNPF $+\mathrm{H})^{+}$ & Asn-Pro & Val-Asn \\
\hline & $b_{5}$ & VPVNP $^{+}$ & cyclo(VPVNP + H) ${ }^{+}$ & Asn-Pro & Val-Asn \\
\hline & $b_{4}$ & $\mathrm{VPVN}^{+}$ & cyclo $(\text {VPVN }+\mathrm{H})^{+}$ & Asn-Val & Val-Asn \\
\hline \multirow[t]{5}{*}{ FPOPFPFI $^{\mathrm{b}}$} & $b_{7}$ & FPOPFPF $^{+}$ & cyclo(FPQPFPF $+\mathrm{H})^{+}$ & GIn-Pro & Phe-Pro \\
\hline & $\mathrm{b}_{6}$ & FPQPFP $^{+}$ & cyclo(FPQPFP $+\mathrm{H})^{+}$ & Gln-Pro & Phe-Pro \\
\hline & $b_{5}$ & FPQPF $^{+}$ & cyclo(FPQPF $+\mathrm{H})^{+}$ & GIn-Pro & Phe-Phe \\
\hline & $b_{4}$ & $\mathrm{FPQP}^{+}$ & cyclo(FPOP + H) + & GIn-Pro & Phe-Pro \\
\hline & $b_{3}$ & $\mathrm{FPO}^{+}$ & cyclo $(\mathrm{FPO}+\mathrm{H})^{+}$ & $-^{\mathrm{c}}$ & $-^{\mathrm{c}}$ \\
\hline \multirow[t]{2}{*}{ APFNSL } & $b_{5}$ & APFNS $^{+}$ & cyclo $(\text {APFNS }+\mathrm{H})^{+}$ & Ala-Pro & Pro-Phe \\
\hline & $b_{4}$ & APFN $^{+}$ & cyclo(APFN + H) ${ }^{+}$ & Ala-Pro & Asn-Ala \\
\hline \multirow[t]{2}{*}{ LPPFI } & $\mathrm{b}_{4}$ & LPPF $^{+}$ & cyclo $(\mathrm{LPPF}+\mathrm{H})^{+}$ & Leu-Pro & Pro-Pro \\
\hline & $b_{3}$ & $\mathrm{LPP}^{+}$ & cyclo $(\mathrm{LPP}+\mathrm{H})^{+}$ & $-{ }^{c}$ & $-{ }^{c}$ \\
\hline \multirow[t]{2}{*}{ FSPLII } & $b_{5}$ & $\mathrm{FSPLI}^{+}$ & cyclo $(\text {FSPLI }+\mathrm{H})^{+}$ & Ser-Pro & Leu-Ile \\
\hline & $\mathrm{b}_{4}$ & $\mathrm{FSPL}^{+}$ & cyclo(FSPL $+\mathrm{H})^{+}$ & Ser-Pro & Phe-Ser \\
\hline FPLII & $\mathrm{b}_{4}$ & $\mathrm{FPLI}^{+}$ & cyclo $(\mathrm{FPLI}+\mathrm{H})^{+}$ & Phe-Pro & Leu-Ile \\
\hline PVNPF & $\mathrm{b}_{4}$ & $\mathrm{PVNP}^{+}$ & cyclo(PVNP $+\mathrm{H})^{+}$ & Pro-Pro & Asn-Pro \\
\hline
\end{tabular}

aWen the CPI dissociates via more than two ring-opening pathways, the main two are listed.

binear precursors of the cyclic peptides showing potential to be anticancer drugs [34, 35, 43].

In the CAD spectra $\left(\mathrm{MS}^{3}\right)$ of the $b_{3}$ ions, the anomalous ions are lowly abundant. Due to containing three residues, the cyclization of the $b_{3}$ ions is possibly incomplete. So the preferential ring-opening amide bonds cannot be determined.

parent ion $b_{6}$ can be inferred as PPLIFS ${ }^{+}$. Another set of ions showing sequential elimination of internal residues are $b_{6}-L, b_{6}-P L, b_{6}-P P L$, and $b_{6}-S P P L$. Their sequences can be deduced as IFSPP ${ }^{+}$, IFSP $^{+}$, IFS $^{+}$, and $\mathrm{IF}^{+}$. The sequence of their linear parent ion $b_{6}$ is inferred as $\mathrm{IFSPPL}^{+}$. To sum up, there are three deduced sequences of the parent ion $b_{6}$, i.e., PLIFSP $^{+}$, PPLIFS ${ }^{+}$, and IFSPPL $^{+}$.

To some extent, the deduction method and the sequencing result described above are very similar to thoseüofüaücyclicüpeptideüsequencingü[ $[9, \ddot{u} 10, \ddot{u} 26, \ddot{u} 27]$.ülf FigureülaüisüaüMS ${ }^{2 \ddot{u}}$ spectrumüofü[Mü+üH $]^{+} \ddot{u}_{\text {ofüaücyclic }}$ peptide, we may determine the sequence of the cyclic peptide as cyclo(PLIFSP). But it is indeed the $\mathrm{MS}^{3}$ spectrum of $b_{6}$ PLIFSP $^{+}$from the linear peptide PLIFSPI. Therefore, it can be assumed that $b_{6}$ PLIFSP $^{+}$ is cyclized to form a CPI cyclo(PLIFSP $+\mathrm{H})^{+}$and the $\mathrm{CPI}$ reopens at different sites to produce the fragment

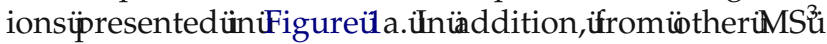
specträ̈̈fübüonsüniFiguresü ündiحifianditheibüonsỉisted inüTableül), üweü̈lsoüobserveülarge-scaleünomalousüons and draw the same conclusion that these $\mathrm{b}$ ions as parent ions have undergone cyclization reactions.

\section{Proposed Mechanism for Cyclization Reaction} of b-Type Ions

The $\mathrm{MS}^{3}$ experiment of $\mathrm{b}_{4}\left(\mathrm{PLIF}^{+}, \mathrm{m} / \mathrm{z}\right.$ 471.6) from

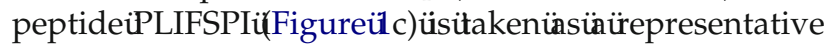
case to discuss the unique fragmentation mechanism. In the $\mathrm{MS}^{3}$ spectrum, not only the normal ions $\boldsymbol{b}_{3}(\mathrm{~m} / \mathrm{z}$ 324.4) and $b_{2}(m / z 211.3)$ exhibiting a sequential loss of residues from $\mathrm{C}$-terminus are observed, but also the anomalous ions $\mathrm{b}_{4}-\mathrm{L}(\mathrm{m} / \mathrm{z} 358.5)$ and $\mathrm{b}_{4}-\mathrm{PL}(\mathrm{m} / \mathrm{z} 261.4)$ displaying a sequential loss of residues from interior are detected.

$\mathrm{MH}^{+} \rightarrow \mathrm{CPI} \rightarrow b_{n}{ }^{\text {rea }}$ pathway. A proposed mechanism is shown in Scheme 2. At the first stage of CAD, the normal ion $b_{4}$ can be formed via the conventional $b_{x}-y_{z}$

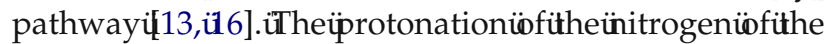
amide bond Phe-Ser lowers the bond stability as well as induces the neighboring carbonyl oxygen to attack the carbon of the amide bond, leading to cleavage of the amide bond to form $b_{4}$ as an oxazolone derivative and aüneutralücounterpartü(PathwayüI) $\ddot{u}[16, \ddot{u} 38]$.üTheïb ${ }_{4}$ ion further dissociates to form $b_{3}$ and $b_{2}$ via conventional 
$b_{n} \rightarrow b_{n-1}$ pathwaysü(PathwayüII)ü[16,ü36].üAtütheüfirst stage of $C A D$, if the $N$-terminal nitrogen attacks the carbon of the amide bond Phe-Ser, $a b_{4}$ CPI will be produced by a head-to-tail cyclization reaction (Pathway III). The fragmentation of the CPI is identical to that of a protonated cyclic peptide, involving proton retransfer, ring opening, and subsequent $b_{n} \rightarrow b_{n-1}$ frag-

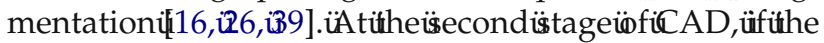
mobile proton locates on the nitrogen of the amide bond Leu-Ile of the CPI, the neighboring carbonyl oxygen will attack the carbon of the amide bond, leading to ring reopening to form the rearranged $b_{4}$ with the Leu residue relocated at the $\mathrm{C}$-terminus (Pathway IV). Subsequently, the anomalous ions $b_{4}-\mathrm{L}$ and $b_{4}-\mathrm{PL}$ are generated via conventional $b_{n} \rightarrow b_{n-1}$ pathways (Pathways V and VI). The series of fragmentations leading to anomalous ions with internal residue losses is tentatively named as $\mathrm{MH}^{+} \rightarrow \mathrm{CPI} \rightarrow \mathrm{b}_{\mathrm{n}}{ }^{\text {rea }}$ pathway.

$b_{n} \rightarrow \mathrm{CPI} \rightarrow b_{n}{ }^{\text {rea }}$ pathway. The $\mathrm{b}_{4}$ CPI can also be formed via other pathways. The linear $b_{4}$ ion may be cyclized by attack of the N-terminal nitrogen on the carbonyl carbon of oxazolone ring to form the CPI (Pathway VII inüSchemeü2) ü[25].üTheüCPIüfurtherüdissociatesütoüproduce the anomalous $b$ ions (Pathways IV, V, and VI). The series of unique fragmentations is tentatively named as $b_{n} \rightarrow C P I \rightarrow b_{n}{ }^{\text {rea }}$ pathway.

The question that remains is the origination of the normal $\boldsymbol{b}$ ions, i.e., $\boldsymbol{b}_{3}\left(m / z\right.$ 324.4) and $\mathbf{b}_{2}(m / z 211.3)$ in Figureülc.üAreitheyüreallyưformedüviaib ${ }_{x}-y_{z}$ (Pathway I) and subsequent $b_{n} \rightarrow b_{n-1}$ pathways (Pathway II)? The answer is that other pathways are possible. As stated above, the CPI reopens at an amide bond whose nitrogen is protonated. At the second stage of CAD, if the CPI reopens at the amide bond Phe-Pro, $b_{4}$ will be reproduced via a $\mathrm{CPI} \rightarrow \mathrm{b}_{\mathrm{n}}{ }^{\text {rea }}$ pathway (Pathway XIII) and be further fragmented to produce $b_{3}$ and $b_{2}$ (Pathway II). In some sense, the ions $b_{3 \dot{u}}$ andib $b_{2 \dot{u}}$ iniFigureülc may also be reassigned as $b_{4}-F$ and $b_{4}-I F$, respectively. Thus, the real origination of these normal $b$ ions needs to be determined (see the Fragmentation of Cyclic Peptide section).

It is worth noting that the $\mathrm{MH}^{+} \rightarrow \mathrm{CPI}$ pathway proposed in this investigation has relationship with the diketopiperazine- $\mathrm{y}_{\mathrm{N}-\mathrm{n}}$ pathway which has been studied byüsomeügroupsü[13,ü16,ü40,ü41].üTheseütwoüpathways (Scheme 3) have the same nucleophile-electrophile mechanism and product structures. When the proton is attached to the produced cyclic peptide to form a CPI ion, it is a $\mathrm{MH}^{+} \rightarrow \mathrm{CPI}$ pathway. On the other hand, when the proton is attached to the produced C-terminal fragment to form a $\mathrm{y}$-type ion, it is a diketopiperazine- $\mathrm{y}_{\mathrm{N}-\mathrm{n}}$ pathway. The alternation of these two fragmentation pathways is induced by a proton transfer between these two product fragments: cyclic peptide and C-terminal fragment. Possibly, these two pathways occur together and transform each other.

The cyclization phenomenon of doubly charged $b$ ionsihasibeenüfoundibyự agüeüetüal.ư[22]üandüaüsimilar mechanism has been proposed for the formation of cyclic $b$ ions and amino acid rearrangement. Following their research, we try to introduce the fragmentation mechanism of cyclic peptides into CPIs and to find some fragmentation rules. Moreover, it should be noted hereithatiHarrison, iPaizsütï̈l.i[25] üpublishedü̈̈̈ommunication about cyclization of singly charged $b$ ions. Their experimental and computational results provide great insight into our proposed mechanism.

To support our proposed mechanisms, four points should be verified by experiments. (1) The assumption that the cyclization reaction requires a free $\mathrm{N}$-terminus will be examined by peptide $\mathrm{N}$-acetylation; (2) the existence of cyclization reaction and CPI will be verified by $\mathrm{MS}^{4}$ and rearranged-ion design; (3) the hypothesis that CPIs have the same fragmentation pattern as protonated cyclic peptides will be tested by fragmentation of synthetic cyclic peptides; (4) the factors affecting the cyclization reaction and the CPI fragmentation will be determined by performing activation-time adjustment and peptide modification as well as by generalizing the fragmentation rules of a number of $b$ ions.

\section{Evidence to Support the Proposed Mechanism for b-Type Ions}

Peptide N-acetylation. To examine whether the cyclization requires a free $\mathrm{N}$-terminus, $\mathrm{N}$-acetylation experiments were performed. Peptides were acetylated in solution and directly subjected to ESI, but the sample cannot be ionized effectively. To obtain efficient ionization, peptideiFSPIPLilanotherüprecursorïfiStylopeptideü ¿[34]üwas acetylated on resin and then cleaved from resin to yield pure N-acetylated peptide. Because the Ser side chains were still protected by $t$-butyl groups during acetylation, there was no acetylation to the Ser residues.

Figureü3aüandübüillustrateüaücomparisonüofüMS ${ }^{3}$ spectra between $b_{5}\left(\right.$ IFSPI $^{+}, m / z$ 558.7) from peptide IFSPIPL and $b_{5}{ }^{\mathrm{E}}\left(\mathrm{CH}_{3} \mathrm{CO}-\mathrm{IFSPI}^{+}, \mathrm{m} / z\right.$ 600.7) from $\mathrm{N}$ acetylated peptide $\mathrm{CH}_{3} \mathrm{CO}$-IFSPIPL. The anomalous ions are presented in the $\mathrm{MS}^{3}$ spectrum of $b_{5}$ (Figureißa).unicontrast,üwhenitheiN-terminusüsỉblocked by an acetyl (+42 Da), these anomalous ions are absent in the $\mathrm{MS}^{3}$ spectrum of $\mathrm{b}_{5}{ }^{\mathrm{E}}$ (Figureü3b).üTheüsame phenomenon can also be found by comparing the $\mathrm{MS}^{3}$ spectra of $b_{4}\left(\right.$ IFSP $\left.^{+}, m / z 445.5\right)$ with that of $b_{4}{ }^{\mathrm{E}}\left(\mathrm{CH}_{3} \mathrm{CO}-\right.$

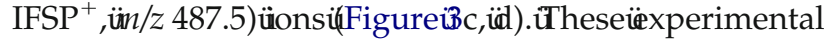
results indicate that the $\mathrm{N}$-acetylation hinder the $\mathrm{N}$ terminal nitrogen from attacking the carbonyl carbon of the C-terminus or one amide bond. Thus, the $\mathrm{MH}^{+} \rightarrow \mathrm{CPI} \rightarrow \mathrm{b}_{\mathrm{n}}{ }^{\text {rea }}$ or $\mathrm{b}_{\mathrm{n}} \rightarrow \mathrm{CPI} \rightarrow \mathrm{b}_{\mathrm{n}}{ }^{\text {rea }}$ pathway no longer takes place, leading to disappearance of anomalous ions.

In addition, in the $\mathrm{MS}^{2}$ spectrum of peptide IFSPIPL, the $\mathrm{y}$ and $\mathrm{b}$ ions are observed with relatively higher intensities (Figure S2A), whereas in that of $\mathrm{N}$-acetylated peptide $\mathrm{CH}_{3} \mathrm{CO}$-IFSPIPL, the $\mathrm{y}$ and $\mathrm{b}^{\mathrm{E}}$ ions is detected with relatively lower intensities (Figure S2B). The pos- 

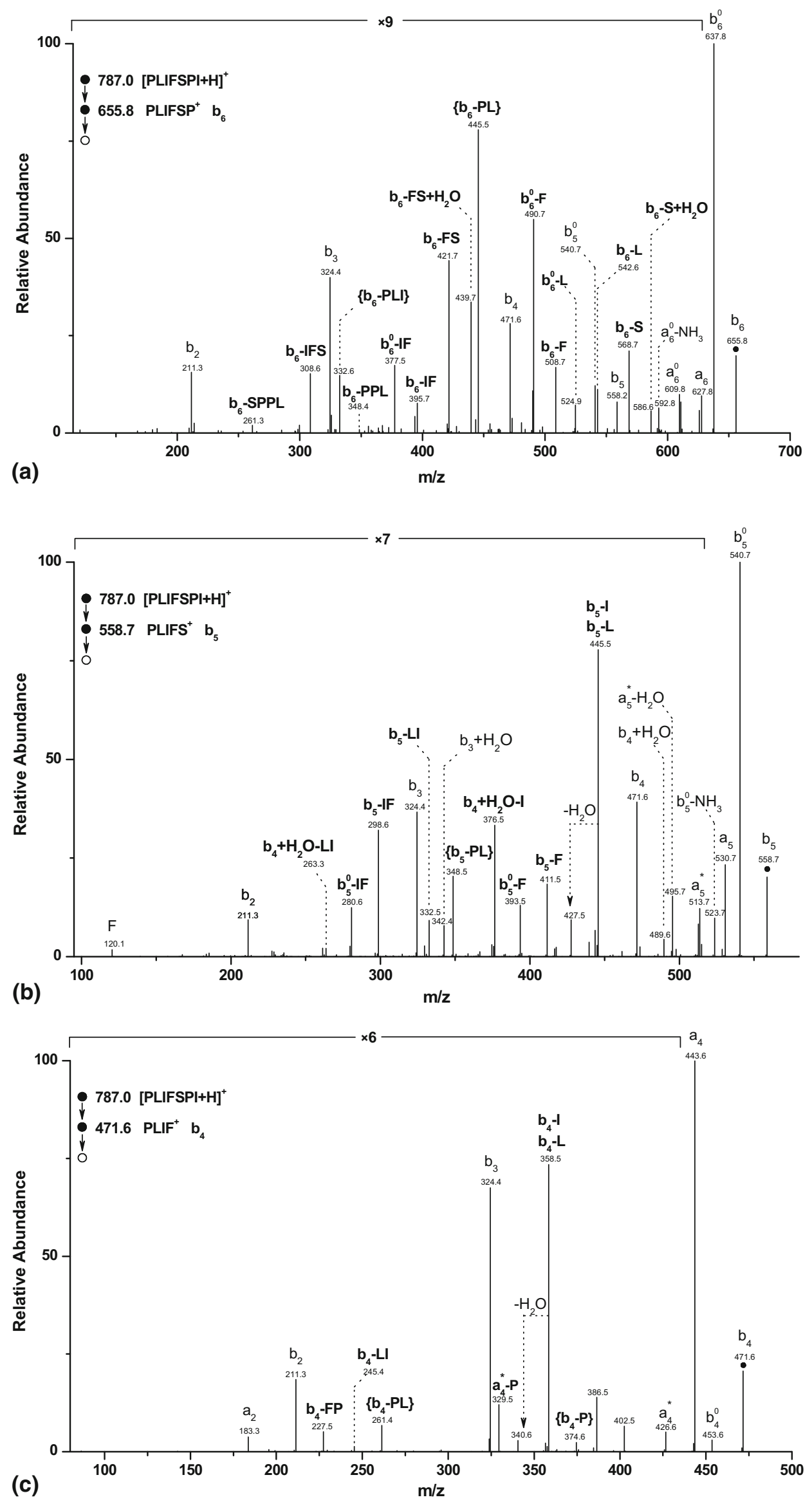

Figure 1. CAD spectra $\left(M^{3}\right)$ of the $(a) b_{6},(\mathbf{b}) b_{5}$, and (c) $b_{4}$ ions from peptide PLIFSPI. In this and the following figures, all of the anomalous ions with internal residue losses are labeled in bold font;

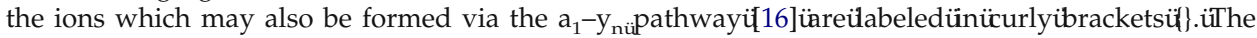
details of the nomenclature are interpreted in the Experimental section. 

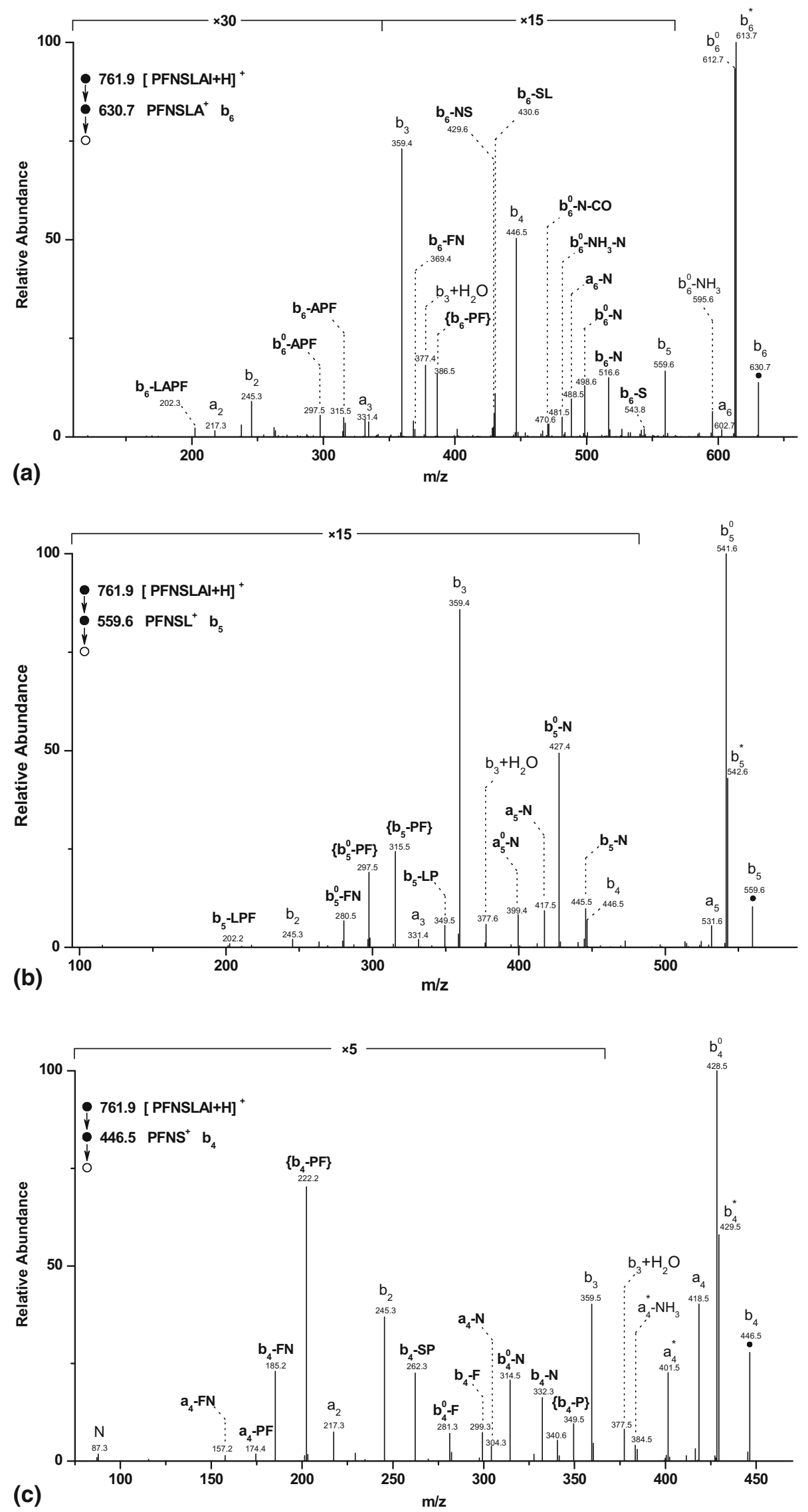

Figure 2. CAD spectra $\left(\mathrm{MS}^{3}\right)$ of the $(\mathbf{a}) \mathrm{b}_{6},(\mathbf{b}) \mathrm{b}_{5}$, and (c) $\mathrm{b}_{4}$ ions from peptide PFNSLAI. 


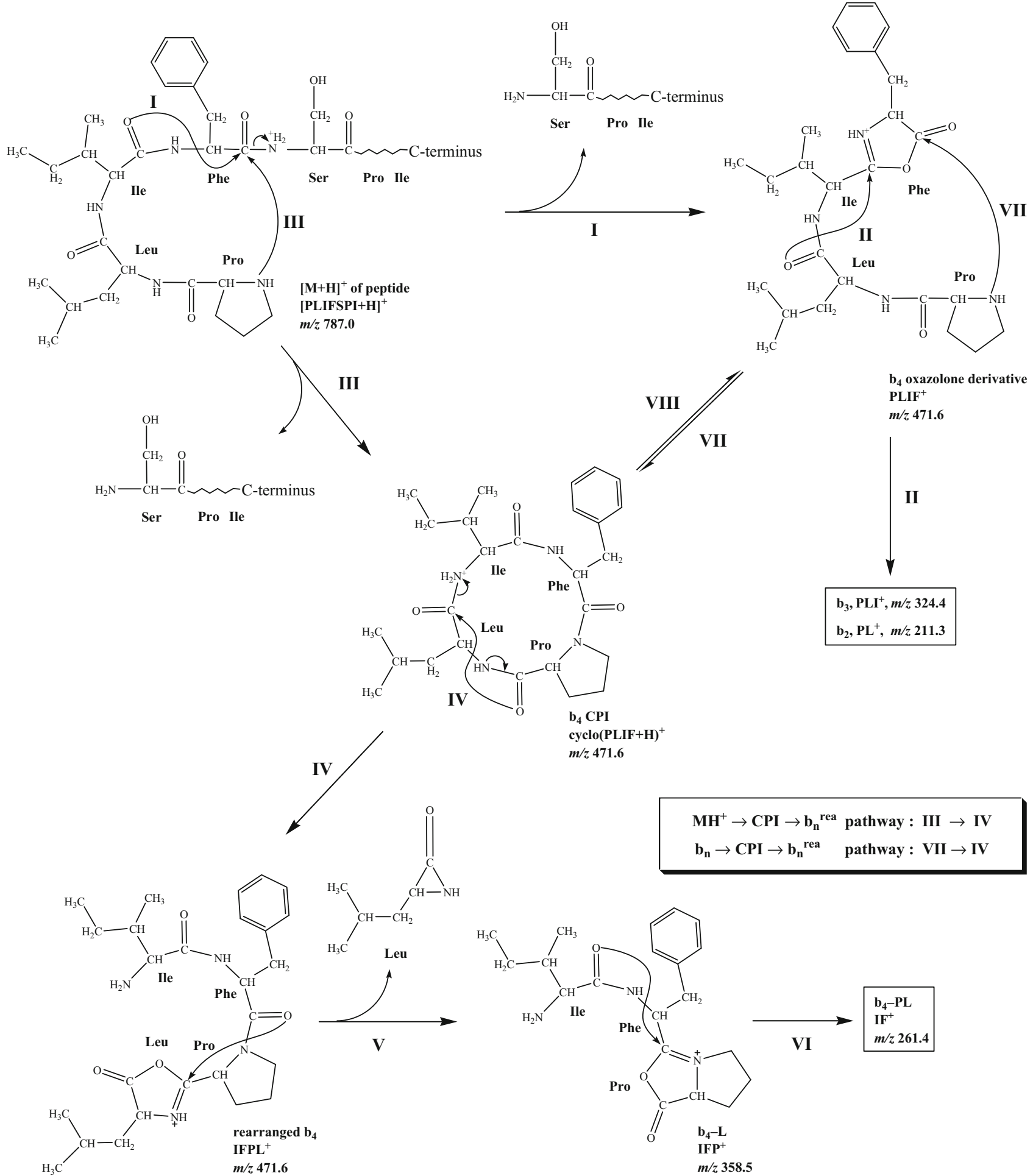

Scheme 2

sible reason is that when the N-terminus is exposed, $\mathrm{b}_{\mathrm{x}}-\mathrm{y}_{\mathrm{z}}$, diketopiperazine- $\mathrm{y}_{\mathrm{N}-\mathrm{n}}$ and $\mathrm{MH}^{+} \rightarrow \mathrm{CPI}$ pathways are available for producing the $\mathrm{y}$ and $\mathrm{b}$ ions. However, as the $\mathrm{N}$-terminus is acetylated, the fragmentations via $\mathrm{MH}^{+} \rightarrow \mathrm{CPI}$ and diketopiperazine- $\mathrm{y}_{\mathrm{N}-\mathrm{n}}$ pathways are ceased, resulting in the decrease of the produced y and $b^{\mathrm{E}}$ ions.
$M S^{4}$ experiment. $\mathrm{MS}^{4}$ experiments were carried out to examine whether the sequences of these anomalous ions are identical with our expectation. $b_{5}-S(m / z$ 471.6) and $b_{5}-F \ddot{u} \mathrm{~m} / z$ 411.5) üniFigureißaüwereïubjecteditoünext stage of CAD to produce $\mathrm{MS}^{4}$ spectra, respectively. In the $\mathrm{MS}^{4}$ spectrum of $\mathrm{b}_{5}-\mathrm{S}$ (Figure S3A), $\mathrm{b}_{5}-\mathrm{FS}(\mathrm{m} / \mathrm{z} 324.4$, $15 \%)$ and $b_{5}$-IFS $(\mathrm{m} / z 211.3,3 \%)$ are observed; in that of 

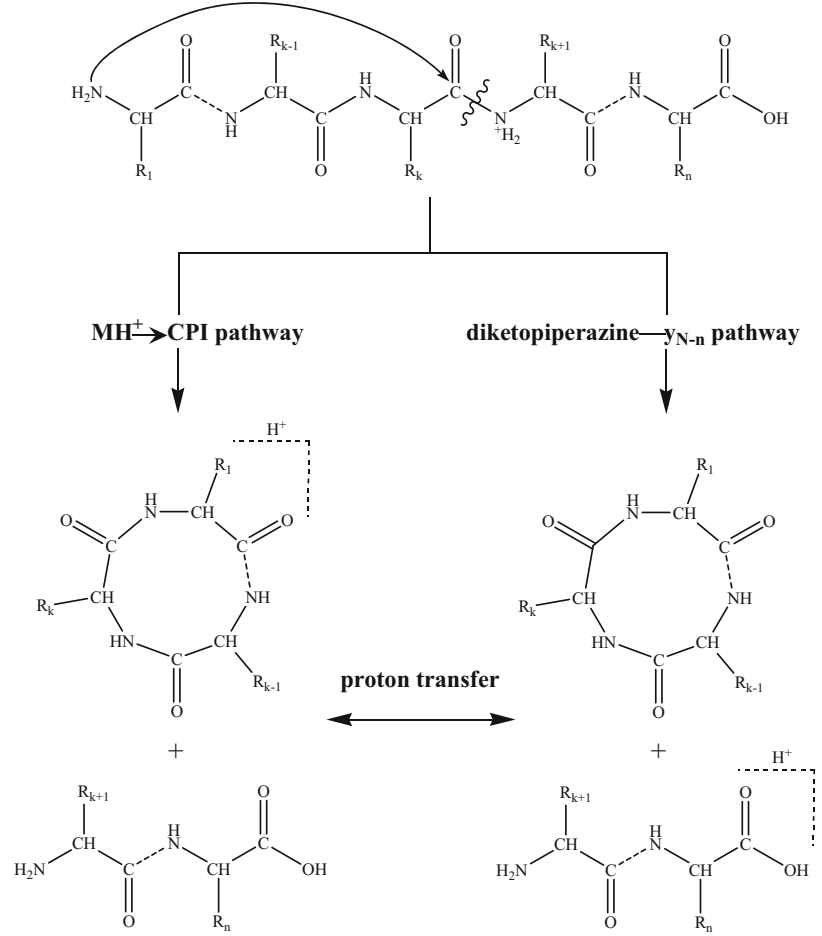

Scheme 3

$\mathrm{b}_{5}-\mathrm{F}$ (Figure S3B), $\mathrm{b}_{5}-\mathrm{IF}(\mathrm{m} / \mathrm{z} 298.4,57 \%)$ is observed. Moreover, the spectra illustrate that $b_{5}-S$ and $b_{5}-F$, which have lost internal residues from the parent ion $b_{5}$, undergo cyclization again to produce anomalous ions with internal residue losses. Further, the $\mathrm{MS}^{4}$ experiment was performed on $b_{5}{ }^{0}$ atüm/z 540.7ü(Figureüßa). From the obtained $\mathrm{MS}^{4}$ spectrum (Figure S3C), fragment ions with losses of internal residues and one molecular water, e.g., $\mathrm{b}_{5}{ }^{0}-\mathrm{F}(\mathrm{m} / \mathrm{z} 393.5,22 \%)$ and $\mathrm{b}_{5}{ }^{0}-\mathrm{IF}$ $(\mathrm{m} / \mathrm{z} 280.6,38 \%)$ are seen, revealing that the parent ion $\mathrm{b}_{5}{ }^{0}$ has undergone cyclization reaction. This also indicatesüthatüniFigureỉßaitheüanomalousüonsüvithüossüof one water molecule, such as $b_{5}{ }^{0}-\mathrm{F}$ and $b_{5}{ }^{0}-\mathrm{IF}$, derive from fragmentation of $b_{5}{ }^{0} \mathrm{CPI}$.

Rearranged-ion design. If the cyclization reaction and the CPI exist during fragmentation, two $b$ ions with different amino acid sequences, which can be cyclized to form the same CPI, may produce identical fragments and CAD spectra. For instance, $\mathrm{PLIFS}^{+}$and $\mathrm{FSPLI}^{+}$can both be cyclized to generate CPI cyclo(FSPLI $+\mathrm{H})^{+}$, and the CPI is able to further dissociate to produce the identical CAD spectra. Thus, peptides FSPLII and FPLII wereüdesignedüandüsynthesized.üFigureü4aüshowsüthe $\mathrm{MS}^{3}$ spectrum of $\mathrm{b}_{5}\left(\mathrm{FSPLI}^{+}, \mathrm{m} / z\right.$ 558.7) from peptide FSPLII, which is designed for comparison with that of the $b_{5}\left(\right.$ PLIFS $^{+}, m / z$ 558.7) from peptide PLIFSPI shown inüFigureülb.üSurprisingly, ütheütwoüspectraühaveüthe identical fragment ions and even the corresponding relative intensities. Similarly, the $\mathrm{MS}^{3}$ spectrum of $\mathrm{b}_{4}$ (FPLI ${ }^{+}, \ddot{u} m / z$ 471.6)üfromüpeptideüFPLIIü(Figureü4b)üis identical to that of $b_{4}\left(\mathrm{PLIF}^{+}, m / z\right.$ 471.6) from peptide
PLIFSPIü(Figureü1c).üTheseüexperimentalüresultsüare consistent with our hypothesis. Interestingly, the $\mathrm{MS}^{3}$ spectrumüofüIFSPI ${ }^{+} \ddot{u}_{\text {(Figureüßa) üisüalmostüidenticalüto }}$

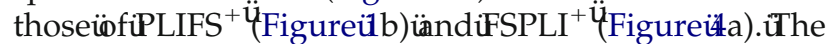
reason is that IFSPI $^{+}$can be cyclized to form cyclo $(\mathrm{IFSPI}+\mathrm{H})^{+}$and $\mathrm{PLIFS}^{+} / \mathrm{FSPLI}^{+}$can be similarly cyclized to form cyclo(IFSPL $+\mathrm{H})^{+}$. Note that the fifth residue of the former CPI is Ile, and that of the latter is Leu. The two CPIs are able to dissociate via similar fragmentation pathways to produce the identical CAD spectra because the isomeric residues Ile and Leu have similar features. The evidences described above strongly prove our assumption about cyclization reaction.

Activation-time adjustment. It has been reported that the similar cyclization reactions of other fragment ions relyüonütimeüscalesüofücollisionalüactivationư19,i20,i22]. For experiments performed at the first stage of CAD $\left(\mathrm{MS}^{2}\right)$, it was easy to adjust the activation time. However, our experiments were carried out using two stages of $\mathrm{CAD}\left(\mathrm{MS}^{3}\right)$, so the cyclization reaction of $\mathrm{b}$ ions may occur at each stage of CAD, leading to two stages of activation times requiring adjustment. As activation time was reduced, relative intensities of some anomalous ions decreased. However, when the activation time at each stage was less than $3 \mathrm{~ms}$, many desired ions could not be detected due to low signals. Thus, it was difficult to measure the critical value of activation time required for cyclization. On the contrary, we used long activation times (30 to $8000 \mathrm{~ms}$ ) to study the effect of activation time on the fragment-ion intensity relationship of $b_{5}$ from PLIFSPI. No fundamental change was found in comparison between the spectra obtained usingüactivationütimesüofü30ü(Figureülb)üandü8000üms (Figure S4). Figure S5 shows the ratios of the fragment-ion intensities versus the activation time, which reflects the competitive relationship between the normal $b_{n} \rightarrow b_{n-1}$ pathway and the anomalous $\mathrm{CPI} \rightarrow \mathrm{b}_{\mathrm{n}}{ }^{\text {rea }} \rightarrow \mathrm{b}_{\mathrm{n}-1}{ }^{\text {rea }}$ pathway. $b_{5}$-L\&I and $b_{5}-F$ arise from fragmentation of CPI via $\mathrm{MH}^{+} \rightarrow \mathrm{CPI} \rightarrow \mathrm{b}_{5}{ }^{\text {rea }} \rightarrow \mathrm{b}_{4}{ }^{\text {rea }}$ and $\mathrm{b}_{5} \rightarrow \mathrm{CPI} \rightarrow \mathrm{b}_{5}{ }^{\text {rea }} \rightarrow \mathrm{b}_{4}{ }^{\text {rea }} ; \mathrm{b}_{4}$ derives from fragmentation of the linear $b_{5}$ ion via $b_{5} \rightarrow b_{4}$ and from fragmentation of the cyclic $b_{5}$ CPI ion via $\mathrm{CPI} \rightarrow \mathrm{b}_{5} \rightarrow \mathrm{b}_{4}$. As the activation time rises, the $\left(\mathrm{b}_{5}-\mathrm{L} \& \mathrm{I}\right) / \mathrm{b}_{4}$ and $\left(b_{5}-F\right) / b_{4}$ ratios both increase, indicating that the long time activation inside an ion trap benefits the occurrence of cyclization reaction. However, the increments of the ratios are not large, revealing that the cyclization reaction and the CPI fragmentation can be mainly accomplished in a normal activation time of $30 \mathrm{~ms}$ at each stage of CAD.

Fragmentation of synthetic cyclic peptide. To explore whether the CPI produced by b ion cyclization has the same fragmentation pattern as protonated cyclic peptide produced by ESI, the cyclic peptide cyclo(PFNSLA) was synthesized and analyzed by ESI-MS/MS to produce a $\mathrm{MS}^{2}$ spectrum (Figure S6), which was used for comparison with the $\mathrm{MS}^{3}$ spectrum of $\mathrm{b}_{6}$ PFNSLA $^{+}$ fromüpeptideiPFNSLAi(Figureiจa).iłCyclo[PFNSLA] ihas 

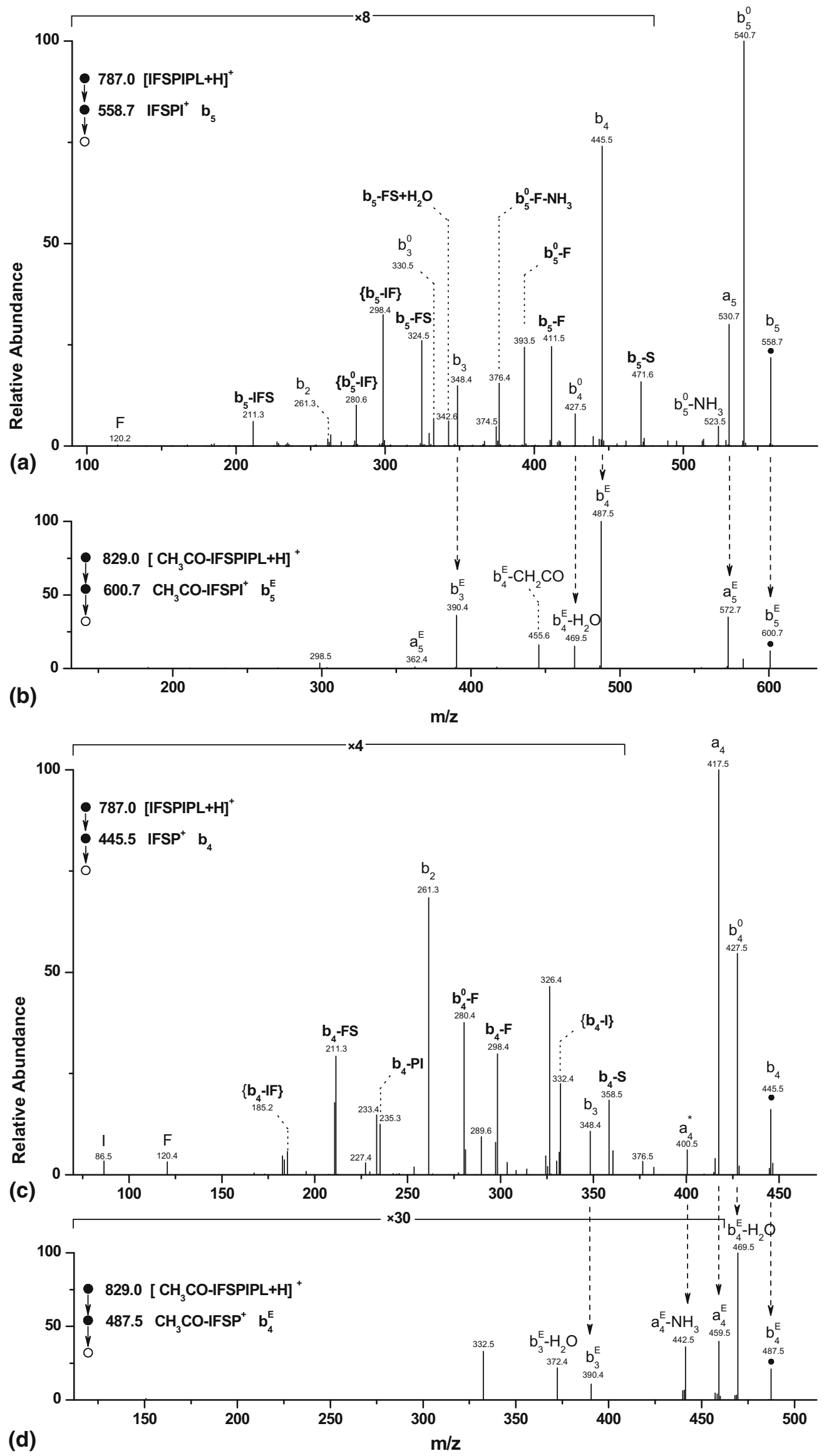

Figure 3. CAD spectra $\left(\mathrm{MS}^{3}\right)$ of (a) the $b_{5}$ ion from peptide IFSPIPL, (b) the $b_{5}{ }^{\mathrm{E}}$ ion from $\mathrm{N}$-acetylated peptide $\mathrm{CH}_{3} \mathrm{CO}$-IFSPIPL, (c) the $\mathrm{b}_{4}$ ion from peptide IFSPIPL, and (d) the $\mathrm{b}_{4}{ }^{\mathrm{E}}$ ion from N-acetylated peptide $\mathrm{CH}_{3} \mathrm{CO}$-IFSPIPL. 

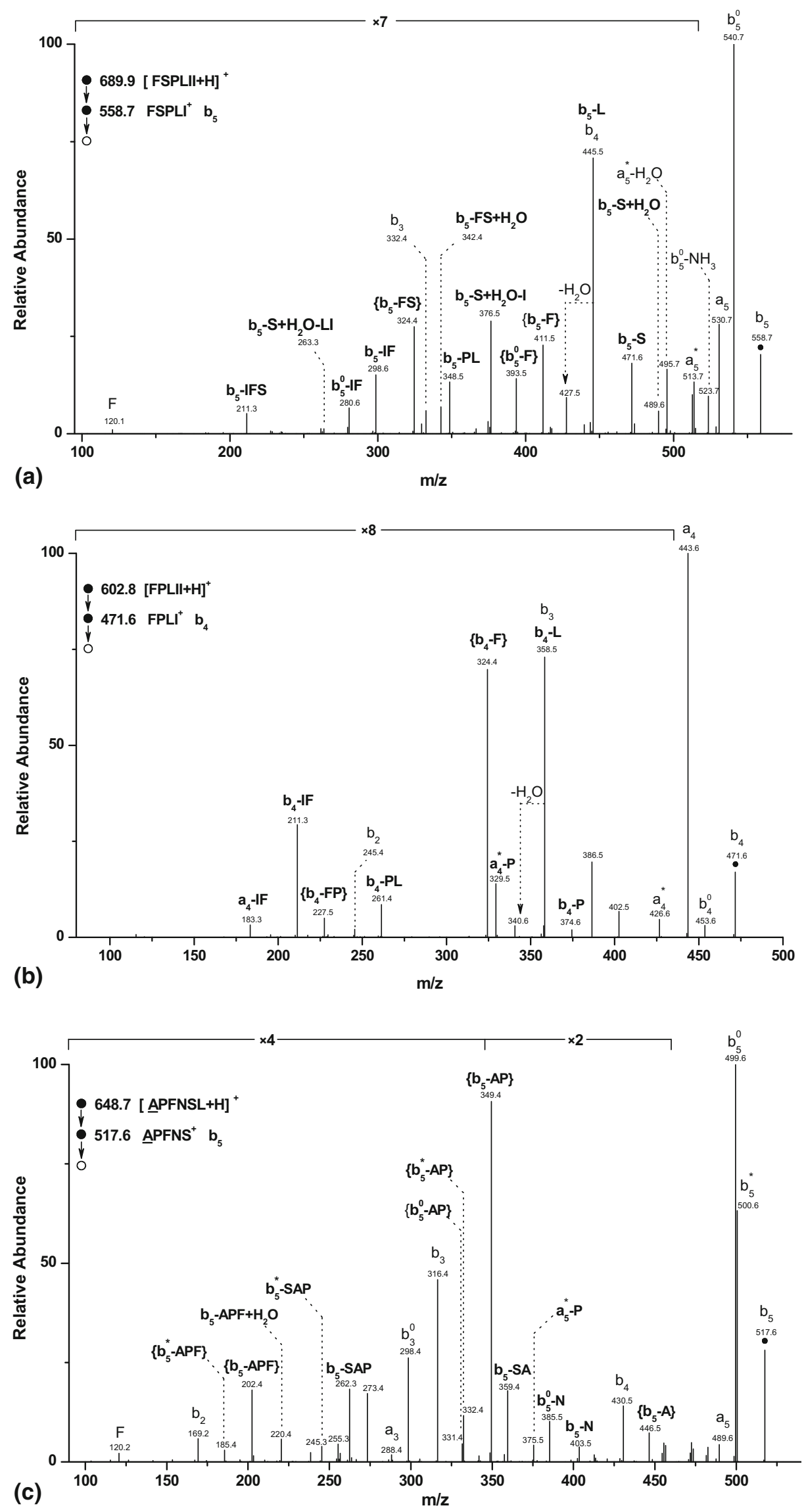

Figure 4. CAD spectra $\left(\mathrm{MS}^{3}\right)$ of $(\mathbf{a})$ the $\mathrm{b}_{5}$ ion from peptide FSPLII, $(\mathbf{b})$ the $\mathrm{b}_{4}$ ion from peptide FPLII, and (c) the $b_{5}$ ion from peptide APFNSL. 
been sequenced by multistep MS/MS in our previous worki[26].)üAsüweïxxpected, itheseitwoüspectraihaveithe same fragment ions and relative intensities, strongly demonstrating that CPIs have the same dissociation feature as protonated cyclic peptides. This experimental result also clarifies the fact that the normal $\mathrm{b}$ ions, such as $\mathrm{b}_{3 \dot{u}}(m / z$ 359.4) ündib 2 2 (m/z 245.3)üniFigurei2a, ümostly originate from CPI fragmentation. Moreover, Harrison etï̈l.í25]üreportedithatitheib ${ }_{5}$ ion from peptide LFGAY gave a breakdown graph, which was very similar to that of protonated cyclo(LFGAY). This finding also confirms the assumption proposed above.

\section{Exploring Predictive Rules for the Unique Fragmentation of b-Type Ions}

Because the $\mathrm{MH}^{+} \rightarrow \mathrm{CPI} \rightarrow b_{n}$ rea or $b_{n} \rightarrow \mathrm{CPI} \rightarrow b_{n}{ }^{\text {rea }}$ pathway includes the processes of cyclization and ring opening, the predictive rules involve two aspects, i.e., predictability of cyclization reaction and predictability of CPI ring opening.

Predictive rules for cyclization reaction. All of the six parentibüonsüniFiguresü ündì, üwhichihaveündergone cyclization reaction, have Pro residues located at Ntermini.üTheiProüresidueüwithüinhighüprotonü̈ffinityi[[28] is easy to initiate a nucleophilic attack on the Cterminus or one amide bond. Do the N-terminal Pro residues contribute to the high-frequency of cyclization reactions? To answer this question, we performed peptide modification. The $\mathrm{b}$ ion $A \mathrm{PFNS}^{+}$was designed to compare its CAD spectrum with that of $\mathrm{PFNS}^{+}$in Figureį̈c.üAnüAlaüresidueüsü̈ddeditoutheiN-terminusüf $\mathrm{PFNS}^{+}$to block the Pro residue without breaking the C-terminalüconformationüinügasüphase.üInüFigureü4c many anomalous ions are presented, demonstrating that $\mathrm{APFNS}^{+}$have also suffered from cyclization. This means that the N-terminal Pro has no obvious relationship with the occurrence of cyclization reactions.

Otherünvestigationsi[19, i2 2] ihaveüdemonstratedithat displacing internal residues cannot prevent a- and $\mathrm{b}^{2+}$-type ions from cyclizing. Nevertheless, for cyclic peptide synthesis in solution or solid phase, the yield of cyclization strongly relies on choice of cyclization sites, i.e.,ütheütwoüterminalüresiduesüofülinearüpeptidesü[42]. This means that the two terminal residues possibly affectibüonücyclizations.iMoreover, üniFigureül $a$, ib, ünd $c, b_{6}\left(\right.$ PLIFSP $\left.^{+}\right), b_{5}\left(\right.$ PLIFS $\left.^{+}\right)$, and $b_{4}\left(\right.$ PLIF $\left.^{+}\right)$as parent ions all undergo cyclization reactions, revealing that the change of the C-terminal residues cannot influence cyclization reactions. Also, the cyclizations of the $b$ ions fromü peptidesü PFNSLAIü (Figureü 2)ü andü IFSPIPL (Figureỉ) üallüsupportüthisüpoint.üAsüaüresult, ütheümost possible factor to affect cyclization reactions is the characteristics of $\mathrm{N}$-terminal residues. To examine whether N-terminal residues control the cyclization process in gas phase, two peptides LPVNPFV and VPVNPFVüprecursorsüöfüAxinastatinißüandül ił43]üwere

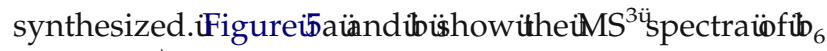
$\left(\mathrm{LPVNPF}^{+}, \mathrm{m} / \mathrm{z}\right.$ 668.8) from peptide LPVNPFV and $\mathrm{b}_{6}$ $\left(V P V N P F^{+}, m / z 654.8\right)$ from peptide $V P V N P F V$, respectively. Apparently, the two $\mathrm{b}$ ions have undergone cyclization reactions. Furthermore, the two $b_{6}$ ions display similar fragmentation patterns. For instance, $\mathrm{b}_{6}-\mathrm{PV}$ at $m / z 472.6$ in panel A corresponds with $\mathrm{b}_{6}-\mathrm{PV}$ at $m / z 458.5$ in panel $\mathbf{B} ; \mathbf{b}_{6}-\mathrm{VN}$ at $m / z 455.6$ in panel $\mathbf{A}$ corresponds with $\mathbf{b}_{6}-\mathrm{VN}$ at $m / z 441.6$ in panel B. Similarly, the phenomenon has also been found in the $\mathrm{MS}^{3}$ spectra of the $b_{5 \dot{u}}$ ionsüfromitheseütwoüpeptidesüFigure $5 c$,üd).iDverall,ünoüevidenceürevealsithatitheücyclization reaction is predictable. In other words, the unique fragmentation reaction is very intensive.

Predictive rules for CPI ring opening. To some extent, the CPI ring opening may be predicted. As discussed above, the CPIs and the protonated cyclic peptides have the same fragmentation pattern. It has been reported that fragmentations of protonated cyclic peptides containing Pro, Asn, Gln, Asn, and Glu always display selectiveüring-openingübehaviorsü[10,ü26,ü44,ü45].üFor example, ütheüamideibondsìXxx-Proü[28]ünndüAsn/GlnXxxü[16,ü29]üshowüenhancedücleavage.üSimilarly,üthe fragmentations of CPIs also display the selective ringopeningübehaviors.üTableül uistsü̈llï̈futheünvestigatedib ions, the formed CPIs and the preferred ring-opening amide bonds, which clearly exhibits the "Pro and Asn/ Gln effects" acting on CPIs. As a result, if we consider CPIs as protonated cyclic peptides, many of the fragmentations will be predictable.

Finally, two questions remain to be addressed. First, the $\mathrm{b}_{6}-\mathrm{S}+\mathrm{H}_{2} \mathrm{O}$ ion at $m / z 586.6$ and the $\mathrm{b}_{6}-\mathrm{FS}+\mathrm{H}_{2} \mathrm{O}$ ionüatüm/z 439.7üareüpresentedüinüFigureüla.üSinceüthe parent $b_{6}$ ion PLIFSP ${ }^{+}$contain a Ser residue, this type of

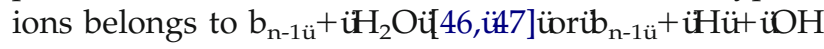
[48]ü̈ons.üTheseüionsücanüalsoübeüfoundüinüotherüCAD specträ̈̈füserine-containingüons. iSecond, üniFigureiॅaüt is observed that $\mathrm{b}_{6}-\mathrm{N}$ at $\mathrm{m} / \mathrm{z} 554.7$ is accompanied by $\mathrm{a}_{6}-\mathrm{N}$ at $m / z$ 526.7. This phenomenon that b-type ions are accompanied by a-type ions can also be observed from otherüspectraü(Figureü5b,üc,üd).üThisüprovesüthatüthe anomalous ions have the features of b-type ions as assumed above.

\section{Cyclization Reaction of Singly Charged a-Type Ions}

Vachetïetïl.iq19] ̈ülescribedithatitheücyclizationüreaction of the singly charged a-type ion accompanied by an $\mathrm{NH}_{3}$ loss can induce an internal residue loss from the second position of $\mathrm{C}$-terminus. This unique fragmentation was observed when a mixture of helium and 5\% xenon was used as collision gas in an ion trap. In our CAD experiments using pure helium as collision gas, the same phenomenon has also been found. In addition, we noted that the internal residues can be eliminated from different positions. 

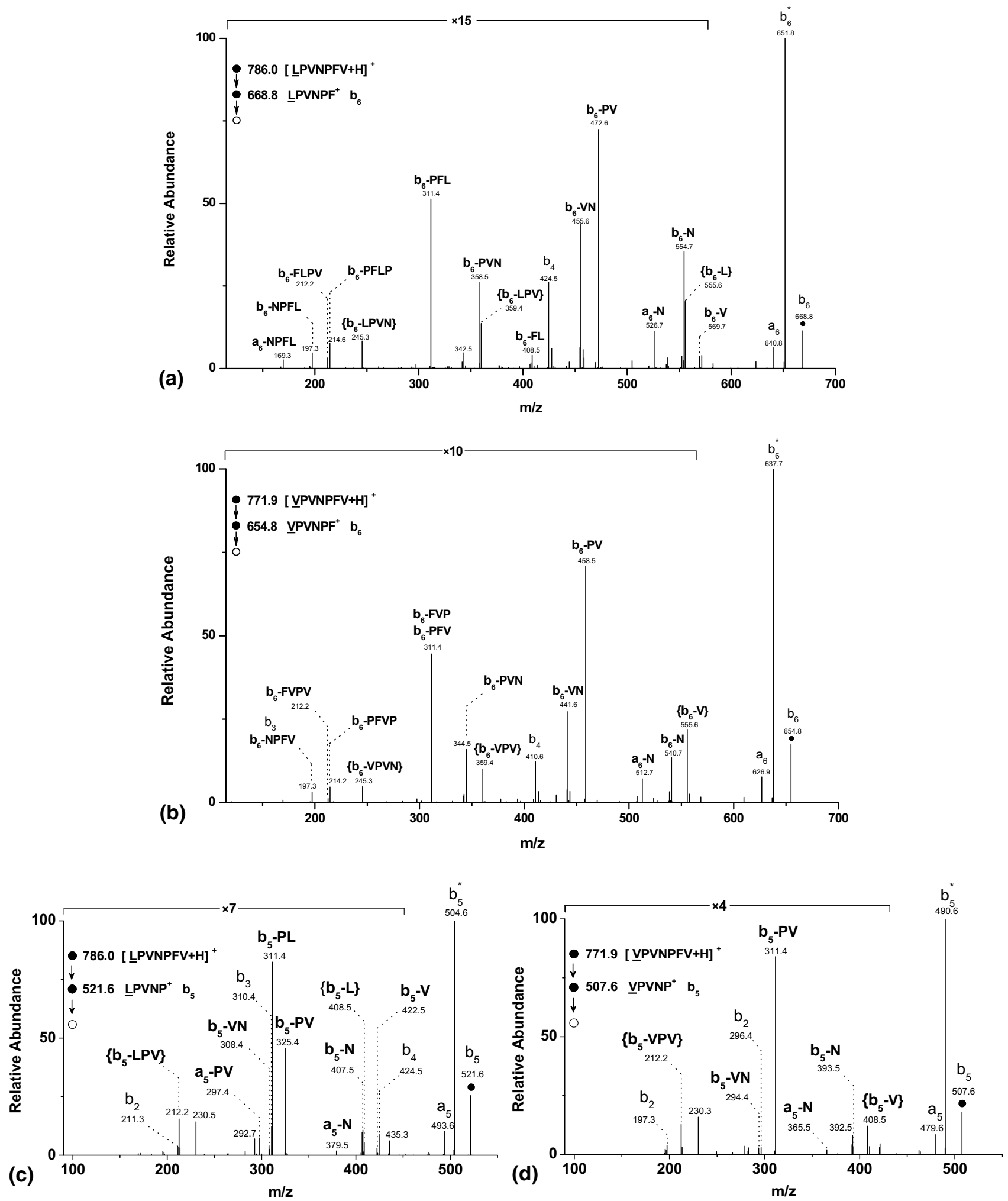

Figure 5. CAD spectra $\left(\mathrm{MS}^{3}\right)$ of the $\mathrm{b}_{6}$ ions from peptides, (a) LPVNPFV and (b) VPVNPFV; CAD spectra $\left(\mathrm{MS}^{3}\right)$ of the $\mathrm{b}_{5}$ ions from peptides, (c) LPVNPFV and (d) VPVNPFV.

Experimental results. In the $\mathrm{MS}^{3}$ spectrum of $\mathrm{a}_{5}$ IF$\mathrm{SPI}^{+}$-COüfromüpeptideưfFSPIPLü(Figureü6), ütheü日nomalous ions $\mathrm{a}_{5}{ }^{*}-\mathrm{P}$ at $m / z 416.5$ and $\mathrm{a}_{5}{ }^{*}-\mathrm{SP}$ at $m / z 329.5$ are presented. In the $\mathrm{MS}^{4}$ experiment on $\mathrm{a}_{5}{ }^{*}-\mathrm{P}$ (Figure
S7A), $a_{5}{ }^{*}-$ SP $(100 \%)$ was detected. The results indicate that the Pro residue is lost from the second position of C-terminus of IFSPI ${ }^{+}-\mathrm{CO}$. Similarly, $\mathrm{a}_{5}{ }^{*}-\mathrm{F}$ at $\mathrm{m} / \mathrm{z} 366.6$ and $a_{5}{ }^{*}-$ IFüatün/z 253.5üareüpresentedüniFigureḯ; ü $_{5}{ }^{*}-$ IF 


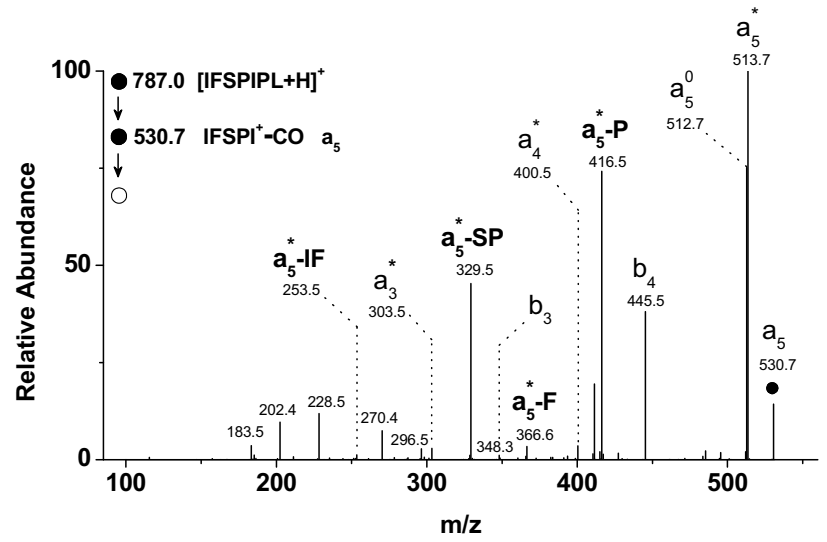

Figure 6. $\mathrm{CAD}$ spectrum $\left(\mathrm{MS}^{3}\right)$ of the $\mathrm{a}_{5}$ ion from peptide IFSPIPL.

$(100 \%)$ was observed in the $\mathrm{MS}^{4}$ experiment on $\mathrm{a}_{5}{ }^{*}-\mathrm{F}$ (Figure S7B). The results demonstrate that the Phe residue is lost from the fourth position of the Cterminus of IFSPI ${ }^{+}-\mathrm{CO}$. When peptide IFSPIPL is Nacetylated, the anomalous fragmentation no longer occurs (Figure S8), indicating that the cyclization also needsüaifreeiN-terminus.üTableỉiuistsitheüparentüa-type ions and the observed anomalous ions in this study. Interestingly, the acquired spectra are always dominated by $\mathrm{a}_{\mathrm{n}}{ }^{*}-\mathrm{P}$ ions, indicating that Pro residues are preferred to lose from interior of parent ion. In other words, the amide bond Pro-Xxx in CPIs formed by a-type ion cyclization is preferred to cleave, which contrasts with the conventional concept that $\mathrm{Xxx}$-Pro is easyitoücleavei[28].

Proposed mechanism. A proposed mechanism of the unique fragmentation is shown in Scheme 4 . The $a_{n}$ ion can be cyclized to form a CPI accompanied by an $\mathrm{NH}_{3}$ lossü(Pathwayüi) ü[19, ì24].üTheüCPIüreopensütoüproduce the rearranged $a_{n}{ }^{*}$ ion (acylium ion or protonated oxazolone) where the second residue (the ' $n-1$ 'th residue) of the C-terminus of the parent ion relocate at the C-terminus of the new ion (Pathways II and III). The rearranged $a_{n}{ }^{*}$ ion with the feature of b-type ions further dissociates via $b_{n} \rightarrow b_{n-1}$ pathways to generate the anomalous ion with loss of the second residue (the ' $n-1$ 'th residue) of C-terminus (Pathway IV). In our experiment, the anomalous ions with losses of residues at other positions have been found as depicted above, indicating that the CPI is able to reopen at other amide bonds (Pathway I in Scheme 5). The ' $k$ 'th residue can be removed by further dissociation of the rearranged $a_{n}{ }^{A}$ ion (Pathway III).

It should be noted that the ring opening of a protonated cyclic peptide is initiated by a proton transfer, whereas the a-type ion CPI is a fixed-charge structure without any mobile protons. Therefore, the "Pro effect" cannot influence CPI ring openings, causing Xxx-Pro no longer to be the preferred cleavage site. Why do amide bonds Pro-Xxx in the CPIs exhibit enhanced cleavage?

Table 2. a-Type ions undergoing cyclization reaction in this investigation

\begin{tabular}{|c|c|c|c|c|c|}
\hline \multirow{2}{*}{$\begin{array}{l}\text { Peptide } \\
\text { IFSPIPL }\end{array}$} & \multicolumn{2}{|c|}{$\begin{array}{l}\text { Parent a-type ions } \\
\text { undergoing } \\
\text { cyclization reaction }^{a}\end{array}$} & \multicolumn{2}{|c|}{$\begin{array}{l}\text { Anomalous fragment ions with internal amino-acid } \\
\text { residue losses }\end{array}$} & \multirow{2}{*}{$\begin{array}{c}\begin{array}{c}\text { Preferred ring-opening } \\
\text { amide bond of } \mathrm{CPI}^{\mathrm{b}}\end{array} \\
\text { Pro-lle }\end{array}$} \\
\hline & $a_{5}$ & $\mid \mathrm{FSPI}^{+}-\mathrm{CO}$ & $\begin{array}{l}a_{5}{ }^{*}-P(m / z 416.5,74 \%) \\
a_{5}{ }^{*}-F(m / z 366.6,3 \%)\end{array}$ & $\begin{array}{l}a_{5}{ }^{*}-\operatorname{SP}(m / z 329.5,45 \%) \\
a_{5}{ }^{*}-\operatorname{IF}(m / z 253.5,1 \%)\end{array}$ & \\
\hline LPVNPFV & $\begin{array}{l}a_{6} \\
a_{5} \\
a_{4}\end{array}$ & $\begin{array}{l}\mathrm{LPVNPF}^{+}-\mathrm{CO} \\
\mathrm{LPVNP}^{+}-\mathrm{CO} \\
\mathrm{LPVN}^{+}-\mathrm{CO}\end{array}$ & $\begin{array}{l}\mathrm{a}_{6}{ }^{*}-\mathrm{P}(\mathrm{m} / \mathrm{z} 526.8,100 \%) \\
\mathrm{a}_{5}{ }^{*}-\mathrm{P}(\mathrm{m} / \mathrm{z} 379.3,100 \%) \\
\mathrm{a}_{4}{ }^{*}-\mathrm{P}(\mathrm{m} / \mathrm{z} 282.2,12 \%)\end{array}$ & $a_{6}{ }^{*}-N P(m / z 412.7,12 \%)$ & $\begin{array}{c}\text { Pro-Phe } \\
-{ }^{c} \\
\text { Pro-Val }\end{array}$ \\
\hline VPVNPFV & $a_{6}$ & $\mathrm{VPVNPF}^{+}-\mathrm{CO}$ & $\begin{array}{l}a_{6}{ }^{*}-\mathrm{P}(\mathrm{m} / \mathrm{z} 512.6,100 \%) \\
\mathrm{a}_{6}{ }^{*}-\operatorname{VNP}(\mathrm{m} / \mathrm{z} 299.6,4 \%)\end{array}$ & $a_{6}{ }^{*}-N P(m / z ~ 398.7,22 \%)$ & Pro-Phe \\
\hline & $a_{5}$ & $\mathrm{VPVNP}^{+}-\mathrm{CO}$ & $a_{5}{ }^{*}-P(m / z 365.5,64 \%)$ & & $-^{\mathrm{c}}$ \\
\hline & $a_{4}$ & $\mathrm{VPVN}^{+}-\mathrm{CO}$ & $\mathrm{a}_{4}{ }^{*}-\mathrm{P}(\mathrm{m} / \mathrm{z} 268.3,7 \%)$ & $a_{4}{ }^{*}-V P(m / z 169.4,5 \%)$ & Pro-Val \\
\hline FPQPFPFI & $a_{7}$ & $\mathrm{FPOPFPF}^{+}-\mathrm{CO}$ & $\begin{array}{l}\mathrm{a}_{7}^{*}-\mathrm{P}(\mathrm{m} / \mathrm{z} 719.9,100 \%) \\
\mathrm{a}_{7}^{*}-\operatorname{PFP}(\mathrm{m} / \mathrm{z} 475.8,59 \%)\end{array}$ & $\mathrm{a}_{7}{ }^{*}-\mathrm{FP}(\mathrm{m} / \mathrm{z} 572.9,44 \%)$ & Pro-Phe \\
\hline & $a_{5}$ & $\mathrm{FPOPF}^{+}-\mathrm{CO}$ & $a_{5}{ }^{*}-P(m / z 475.7,100 \%)$ & $a_{5}{ }^{*}-\mathrm{FP}(\mathrm{m} / \mathrm{z} 328.5,42 \%)$ & Pro-GIn \\
\hline PFNSLAI & $a_{6}$ & PFNSLA $^{+}-\mathrm{CO}$ & $\begin{array}{l}a_{6}{ }^{*}-P(m / z 488.6,44 \%) \\
a_{6}{ }^{*}-S(m / z 498.6,17 \%)\end{array}$ & $\begin{array}{l}\mathrm{a}_{6}{ }^{*}-\mathrm{L}(\mathrm{m} / \mathrm{z} 472.6,19 \%) \\
\mathrm{a}_{6}{ }^{*}-\mathrm{NS}(\mathrm{m} / \mathrm{z} 384.7,14 \%)\end{array}$ & Pro-Phe \\
\hline & $a_{5}$ & $\mathrm{PFNSL}^{+}-\mathrm{CO}$ & $\begin{array}{l}a_{5}{ }^{*}-P(m / z ~ 417.5,15 \%) \\
a_{5}{ }^{*}-N S(m / z ~ 313.5,9 \%)\end{array}$ & $a_{5}{ }^{*}-\mathrm{S}(m / z 427.6,9 \%)$ & Pro-Phe \\
\hline PLIFSPI & $a_{5}$ & $\mathrm{PLIFS}^{+}-\mathrm{CO}$ & $\begin{array}{l}a_{5}{ }^{*}-P(m / z 416.8,11 \%) \\
a_{5}{ }^{*}-P L(m / z 303.6,5 \%)\end{array}$ & $a_{5}{ }^{*}-\mathrm{L}(m / z 400.6,2 \%)$ & Pro-Leu \\
\hline & $a_{4}$ & $\mathrm{PLIF}^{+}-\mathrm{CO}$ & $\mathrm{a}_{4}{ }^{*}-\mathrm{P}(\mathrm{m} / \mathrm{z} 346.5,1 \%)$ & $\mathrm{a}_{4}{ }^{*}-\mathrm{L} / \mathrm{I}(\mathrm{m} / \mathrm{z} 313.4,11 \%)$ & $-^{c}$ \\
\hline FSPLII & $a_{5}$ & $\mathrm{FSPLI}^{+}-\mathrm{CO}$ & $\begin{array}{l}a_{5}{ }^{*}-P(m / z 416.6,8 \%) \\
a_{5}{ }^{*}-F(m / z 366.6,2 \%)\end{array}$ & $a_{5}{ }^{*}-S P(m / z 329.5,5 \%)$ & Pro-Leu \\
\hline & $a_{4}$ & $\mathrm{FSPL}^{+}-\mathrm{CO}$ & $\mathrm{a}_{4}{ }^{*}-\mathrm{P}(\mathrm{m} / \mathrm{z} 303.3,100 \%)$ & & Pro-Leu \\
\hline LPPFI & $a_{4}$ & $\mathrm{LPPF}^{+}-\mathrm{CO}$ & $a_{4}{ }^{*}-P(m / z 313.4,100 \%)$ & & Pro-Pro/Phe \\
\hline
\end{tabular}

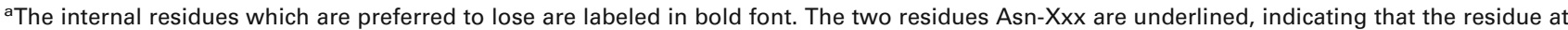
the right position of Asn is easy to lose.

bWhen the CPI dissociates via more than one ring-opening pathway, the preferred one is listed.

${ }^{\mathrm{c}}$ The preferred ring-opening amide bond cannot be determined. 

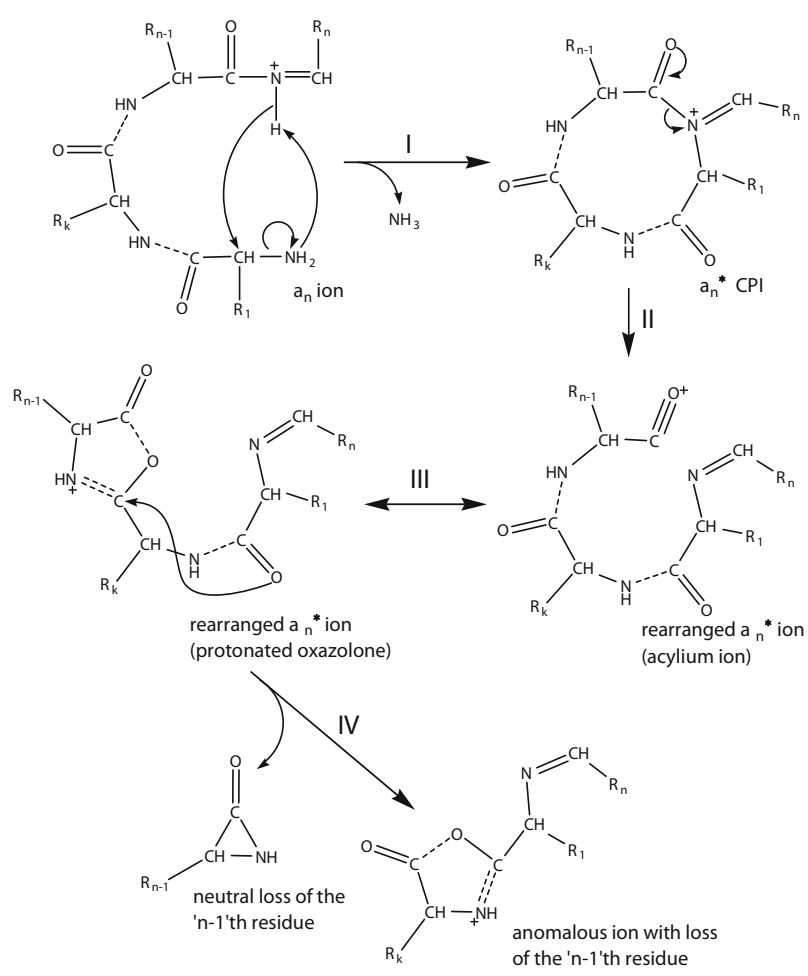

Scheme 4

A tentative explanation is given as follows. The ringopening pathway of the CPI is reversible (Pathways I and II in Scheme 5). In the process of fragmentation, if the rearranged $\mathrm{a}_{\mathrm{n}}{ }^{*}$ ion never dissociate timely to produce anomalous ions with internal residue losses (Pathway III), the reversible reaction will occur to reform the CPI (Pathway II). The $a_{n}{ }^{*}$ acylium ion can transform to the protonated oxazolone ion. The latter structure has a mobile proton, so it can be affected by the "Pro effect". Therefore, if a Pro residue is relocated at the C-terminus of the rearranged $a_{n}{ }^{*}$ ion, the amide bond Xxx-Pro will be preferred to cleave via the $b_{n} \rightarrow b_{n-1}$ pathway to form an $\mathrm{a}_{\mathrm{n}}{ }^{*}-\mathrm{P}$ ion (Pathway III), driving the reversible reaction toward right orientation (Pathway I). On the basisüofithei̛'pathwaysünücompetition" ïmodeli[16], ithe ring-opening pathways of the $\mathrm{CPI}$ are competitive. As a result, the amide bond Pro- $\mathrm{Xxx}$ in CPI is preferred to dissociate. In a word, the "Pro effect" cannot act on ring opening of CPI, but can act on dissociation of the rearranged $\mathrm{a}_{\mathrm{n}}{ }^{*}$ ion formed by ring opening of CPI. Consequently, it can be concluded that the enhanced cleavage of $a_{n}{ }^{*}$ ion at Xxx-Pro results in the preferred ring opening of CPI at Pro-Xxx. Additionally, another interesting finding can further support this explanation. FromüTableüRüitüisüfoundüthatütheüresidueüatütheüright position of Asn is easy to lose, revealing that the right amide bond of Asn-Xxx-Xxx in CPI is preferential to cleave. The phenomenon also indicates that the "Asn effect" cannot act on ring opening of CPI, but can act on dissociation of the rearranged $a_{n}{ }^{*}$ ion.

\section{Conclusions}

In this investigation, it was found that internal amino acid residues could be lost from singly charged b- and a-type ions during multistage CAD. Our results indicate that the unique fragmentations are induced by cyclization reactions.

\section{b-Type Ions}

The cyclization of $b$ ion is initiated by a nucleophilic attack of the N-terminal nitrogen on the carbonyl carbon at C-terminus or at one amide bond to produce a CPI. Subsequently, the CPI is reopened at another position and an internal residue is relocated at the $\mathrm{C}$-terminus. The ring-opened structure further dissociates via $b_{n} \rightarrow b_{n-1}$ pathways to produce the anomalous ions with internal residue losses. This reaction can be mainly completed in activation time of $30 \mathrm{~ms}$. The CPI produced by $b$ ion cyclization displays the same fragmentation pattern as the protonated cyclic peptide produced by ESI, and shows selective ring-opening behaviors owing to the "Pro and Asn/Gln effects".

\section{a-Type Ions}

The a-type ion can be cyclized to form a CPI accompanied by an $\mathrm{NH}_{3}$ loss. The CPI may then reopen at different positions to generate rearranged $\mathrm{a}_{\mathrm{n}}{ }^{*}$ ions with the feature of b-type ions. The rearranged $a_{n}{ }^{*}$ ions further dissociate via $b_{n} \rightarrow b_{n-1}$ pathways to form anomalous ions with internal residue losses. The CPI is a fixed-charge structure, whereas the rearranged $\mathrm{a}_{\mathrm{n}}{ }^{*}$ ion has a mobile proton. Therefore, the "Pro and Asn effects" cannot act on the former but can act on the latter.

Overall, we studied a limited number of synthetic peptides, so we cannot yet conclude that the cyclizations of b- and a-type ions are very general phenomena for other peptides, such as tryptic and natural peptides. If the phenomena receive further attention, the new cyclization reactions of other ions will possibly be discovered and the misidentification of fragments and sequences of peptides will be avoided.

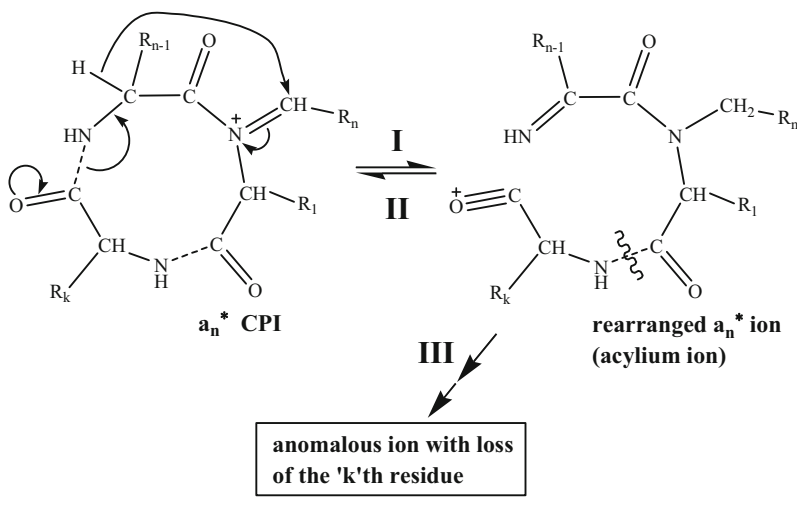

Scheme 5 


\section{Acknowledgments}

This work was supported by the Research Fund for the Doctoral Program of Higher Education of China (no. 20050056061), the Natural Science Foundation of China (no. 20306023), the Program of Introducing Talents of Discipline to Universities of China (no. B06006), and the Tianjin Science and Technology Commission of China (no. F305038). The authors thank Dr. Brandon Emme and Dr. Jan Chen Blaagaard for their careful revisions and helpful comments. They also thank Yongwei Wang and Xiaojuan Sun from Thermo Electron Co. for technical assistance.

\section{References}

1. Domon, B.; Aebersold, R. Mass Spectrometry and Protein Analysis. Science 2006, 312, 212-217.

2. Aebersold, R.; Goodlett, D. R. Mass Spectrometry in Proteomics. Chem. Rev. 2001, 101, 269-295.

3. Wysocki, V. H.; Resing, K. A.; Zhang, Q. F.; Cheng, G. L. Mass Spectrometry of Peptides and Proteins. Methods 2005, 35, 211-222.

4. Forbes, A. J.; Patrie, S. M.; Taylor, G. K.; Kim, Y. B.; Jiang, L. H.; Kelleher, N. L. Targeted Analysis and Discovery of Posttranslational Modifications in Proteins from Methanogenic Archaea by Top-Down MS. Proc. Natl. Acad. Sci. U.S.A. 2004, 101, 2678-2683.

5. Zhong, H. Y.; Zhang, Y.; Wen, Z. H.; Li, L. Protein Sequencing by Mass Analysis of Polypeptide Ladders After Controlled Protein Hydrolysis. Nat. Biotechnol. 2004, 22, 1291-1296.

6. Dworzanski, J. P.; Snyder, A. P.; Chen, R.; Zhang, H. Y.; Wishart, D.; Li, L. Identification of Bacteria Using Tandem Mass Spectrometry Combined with a Proteome Database and Statistical Scoring. Anal. Chem. 2004, 76, 2355-2366.

7. Souza, B. M.; Marques, M. R.; Tomazela, D. M.; Eberlin, M. N.; Mendes, M. A.; Palma, M. S. Mass Spectrometric Characterization of Two Novel Inflammatory Peptides from the Venom of the Social Wasp Polybia paulista. Rapid Commun. Mass Spectrom. 2004, 18, 1095-1102.

8. Brinkworth, C. S.; Bowie, J. H.; Bilusich, D.; Tyler, M. J. The rothein peptides from the skin secretion of Roth's tree frog Litoria rothii. Sequence determination using positive and negative ion electrospray mass spectrometry. Rapid Commun. Mass Spectrom. 2005, 19, 2716-2724.

9. Williams, S. M.; Brodbelt, J. S. MS ${ }^{n}$ Characterization of Protonated Cyclic Peptides and Metal Complexes. J. Am. Soc. Mass Spectrom. 2004, $15,1039-1054$

10. Ngoka, L. C. M.; Gross, M. L. Multistep Tandem Mass Spectrometry for Sequencing Cyclic Peptides in an Ion-Trap Mass Spectrometer. J. Am. Soc. Mass Spectrom. 1999, 10, 732-746.

11. Taylor, S. W.; Kassel, D. B.; Tincu, J. A.; Craig, A. G. Fragmentation of Tunichrome Sp-1 is Dominated by an Unusual Gas-Phase Intramolecular Rearrangement. J. Mass Spectrom. 2003, 38, 1105-1109.

12. O'Hair, R. A. J. The Role of Nucleophile-Electrophile Interactions in the Unimolecular and Bimolecular Gas-Phase Ion Chemistry of Peptides and Related Systems. J. Mass Spectrom. 2000, 35, 1377-1381.

13. Polce, M. J.; Ren, D.; Wesdemiotis, C. Dissociation of the Peptide Bond in Protonated Peptides. J. Mass Spectrom. 2000, 35, 1391-1398.

14. Schlosser, A.; Lehmann, W. D. Five-Membered Ring Formation in Unimolecular Reactions of Peptides: A Key Structural Element Controlling Low-Energy Collision-Induced Dissociation of Peptides. J. Mass Spectrom. 2000, 35, 1382-1390.

15. Wysocki, V. H.; Tsaprailis, G.; Smith, L. L.; Breci, L. A. Mobile and Localized Protons: A Framework for Understanding Peptide Dissociation. J. Mass Spectrom. 2000, 35, 1399-1406.

16. Paizs, B.; Suhai, S. Fragmentation Pathways of Protonated Peptides. Mass Spectrom. Rev. 2005, 24, 508-548.

17. Tang, X. J.; Thibault, P.; Boyd, R. K. Fragmentation Reactions of Multiply-Protonated Peptides and Implications for Sequencing by Tandem Mass Spectrometry with Low-Energy Collision-Induced Dissociation. Anal. Chem. 1993, 65, 2824-2834

18. Tang, X. J.; Boyd, R. K. Rearrangements of Doubly Charged Acylium ions from Lysyl and Ornithyl Peptides. Rapid Commun. Mass Spectrom. 1994, 8, 678-686.

19. Vachet, R. W.; Bishop, B. M.; Erickson, B. W.; Glish, G. L. Novel Peptide Dissociation: Gas-Phase Intramolecular Rearrangement of Internal Amino Acid Residues. J. Am. Chem. Soc. 1997, 119, 5481-5488.

20. Craig, A. G.; Taylor, S. W. Fragmentation of a Novel Marine Peptide, Plicatamide, Involves an Unusual Gas-Phase Intramolecular Rearrangement. J. Am. Soc. Mass Spectrom. 2001, 12, 470-474.

21. Fuchs, R.; Budzikiewicz, H. Rearrangement Reactions in the Electrospray Ionization Mass Spectra of Pyoverdins. Int. J. Mass Spectrom. 2001, 210, 603-612.

22. Yague, J.; Paradela, A.; Ramos, M.; Ogueta, S.; Marina, A.; Barahona, F.; de Castro, J. A. L.; Vazquez, J. Peptide Rearrangement During Quadrupole Ion Trap Fragmentation: Added Complexity to MS/MS Spectra. Anal. Chem. 2003, 75, 1524-1535.
23. Brinkworth, C. S.; Bilusich, D.; Bowie, J. H. The Unusual Loss of an Internal $\mathrm{Val}$ Residue from the $(\mathrm{M}-\mathrm{H})^{-}$parent anions of the antimicrobial peptide citropin 1.1 and Synthetically Modified Analogues Fragmentations which Require a Specific Conformation of the Decomposing Anion. Int. J. Mass Spectrom. 2004, 236, 43-53.

24. Harrison, A. G.; Young, A. B. Fragmentation of Protonated Oligoalanines: Amide Bond Cleavage and Beyond. J. Am. Soc. Mass Spectrom. 2004, 15, 1810-1819.

25. Harrison, A. G.; Young, A. B.; Bleiholder, C.; Suhai, S.; Paizs, B. Scrambling of Sequence Information in Collision-Induced Dissociation of Peptides. J. Am. Chem. Soc. 2006, 128, 10364-10365.

26. Jia, C. X.; Qi, W.; He, Z. M.; Qiao, B. Multistage Collisionally Activated Decomposition in an Ion Trap for Identification of Sequences, Structures and $b_{n} \rightarrow b_{n-1}$ fragmentation pathways of protonated cyclic peptides. Eur. J. Mass Spectrom. 2006, 12, 235-245

27. Stefanowicz, P. Electrospray Mass Spectrometry and Tandem Mass Spectrometry of the Natural Mixture of Cyclic Peptides from Linseed. Eur. J. Mass Spectrom. 2004, 10, 665-671.

28. Grewal, R. N.; El Aribi, H.; Harrison, A. G.; Siu, K. W. M.; Hopkinson, A. C. Fragmentation of Protonated Tripeptides: The Proline Effect Revisited. J. Phys. Chem. B 2004, 108, 4899-4908.

29. Jonsson, A. P.; Bergman, T.; Jornvall, H.; Griffiths, W. J.; Bratt, P.; Stromberg, N. Gln-Gly Cleavage: Correlation Between Collision-Induced Dissociation and Biological Degradation. J. Am. Soc. Mass Spectrom. 2001, 12 $337-342$.

30. Harrison, A. G. Fragmentation Reactions of Protonated Peptides Containing Glutamine or Glutamic Acid. J. Mass Spectrom. 2003, 38, 174-187.

31. Jia, C. X.; Oi, W.; He, Z. M.; Yang, H. M.; Qiao, B. Synthesis of Heptapeptides and Analysis of Sequence by Tandem Ion Trap Mass Spectrometry. Cent. Eur. J. Chem. 2006, 4, 285-298.

32. Roepstorff, P.; Fohlman, J. Proposal for a Common Nomenclature for Sequence Ions in Mass Spectra of Peptides. Biomed. Mass Spectrom. 1984, 11,601 .

33. Biemann, K. Contributions of Mass Spectrometry to Peptide and Protein Structure. Biomed. Environ. Mass Spectrom. 1988, 16, 99-111.

34. Pettit, G. R.; Lippert, J. W.; Taylor, S. R.; Tan, R.; Williams, M. D Synthesis of Phakellistatin 11: A Micronesia (Chuuk) Marine Sponge Cyclooctapeptide. J. Nat. Prod. 2001, 64, 883-891.

35. Forns, P.; Piro, J.; Cuevas, C.; Garcia, M.; Rubiralta, M.; Giralt, E.; Diez A. Constrained Derivatives of Stylostatin 1. 1. Synthesis and Biological Evaluation as Potential Anticancer Agents. J. Med. Chem. 2003, 46, 5825-5833.

36. Vachet, R. W.; Ray, K. L.; Glish, G. L. Origin of Product Ions in the MS/MS Spectra of Peptides in a Quadrupole Ion Trap. J. Am. Soc. Mass Spectrom. 1998, 9, 341-344.

37. Paizs, B.; Szlavik, Z.; Lendvay, G.; Vekey, K.; Suhai, S. Formation of $\mathrm{a}_{2}{ }^{+}$ ions of protonated peptides. An ab Initio Study. Rapid Commun. Mass Spectrom. 2000, 14, 746-755.

38. Chen, X. H.; Turecek, F. Simple b-Ions Have Cyclic Oxazolone Structures. A Neutralization-Reionization Mass Spectrometric and Computational Study of Oxazolone Radicals. J. Am. Soc. Mass Spectrom. 2005 16, 1941-1956.

39. Jegorov, A.; Paizs, B.; Kuzma, M.; Zabka, M.; Landa, Z.; Sulc, M.; Barrow, M. P.; Havlicek, V. Extraribosomal Cyclic Tetradepsipeptides Beauverolides: Profiling and Modeling the Fragmentation Pathways. J. Mass Spectrom. 2004, 39, 949-960.

40. Paizs, B.; Suhai, S. Towards Understanding the Tandem Mass Spectra of Protonated Oligopeptides. 1: Mechanism of Amide Bond Cleavage. J. Am. Soc. Mass Spectrom. 2004, 15, 103-113.

41. Smith, L. L.; Herrmann, K. A.; Wysocki, V. H. Investigation of GasPhase Ion Structure for Proline-Containing $\mathrm{b}_{2}$ Ion. J. Am. Soc. Mass Spectrom. 2006, 17, 20-28.

42. Davies, J. S. The Cyclization of Peptides and Depsipeptides. J. Pept. Sci. 2003, 9, 471-501.

43. Pettit, G. R.; Gao, F.; Cerny, R. L.; Doubek, D. L.; Tackett, L. P.; Schmidt J. M.; Chapuis, J. C. Antineoplastic Agents. 278. Isolation and Structure of Axinastatins 2 and 3 from a Western Caroline Island Marine Sponge. J. Med. Chem. 1994, 37 1165-1168.

44. Eckart, K. Mass Spectrometry of Cyclic Peptides. Mass Spectrom. Rev. 1994, 13, 23-55.

45. Schilling, B.; Wang, W.; McMurray, J. S.; Medzihradszky, K. F. Fragmentation and Sequencing of Cyclic Peptides by Matrix-Assisted Lase Desorption/Ionization Post-Source Decay Mass Spectrometry. Rapid Commun. Mass Spectrom. 1999, 13, 2174-2179.

46. Vachet, R. W.; Asam, M. R.; Glish, G. L. Secondary Interactions Affecting the Dissociation Patterns of Arginine-Containing Peptide Ions. J. Am. Chem. Soc. 1996, 118, 6252-6256.

47. Fang, S. P.; Takao, T.; Satomi, Y.; Mo, W. J.; Shimonishi, Y. Novel Rearranged Ions Observed for Protonated Peptides via Metastable Decomposition in Matrix-Assisted Laser Desorption/Ionization Timeof-Flight Mass Spectrometry. J. Am. Soc. Mass Spectrom. 2000, 11, 345-351.

48. Sharp, J. S.; Tomer, K. B. Formation of $\left[b_{(n-1)}+\mathrm{OH}+\mathrm{H}\right]^{+}$Ion Structural Analogs by Solution-Phase Chemistry. J. Am. Soc. Mass Spectrom. 2005, $16,607-621$. 